\title{
Blocking the Interaction between EphB2 and ADDLs by a Small Peptide Rescues Impaired Synaptic Plasticity and Memory Deficits in a Mouse Model of Alzheimer's Disease
}

\author{
Xiao-Dong Shi, ${ }^{1,2 *}$ Kai Sun, ${ }^{1,2,3 *}$ Rui Hu, ${ }^{1,2 *}$ Xiao-Ya Liu, ${ }^{1,2}$ Qiu-Mei Hu, ${ }^{1,2}$ Xiao-Yu Sun, ${ }^{1,2}$ Bin Yao, ${ }^{1,2}$ Nan Sun, ${ }^{1,2}$ \\ Jing-Ru Hao, ${ }^{1,2}$ Pan Wei, ${ }^{1,2}$ Yuan Han, ${ }^{1,2}$ and $\mathbb{C C a n ~ G a o}^{1,2}$ \\ IJiangsu Province Key Laboratory of Anesthesiology and ${ }^{2}$ Jiangsu Province Key Laboratory of Anesthesia and Analgesia Application, Xuzhou Medical \\ University, Xuzhou, Jiangsu 221004, China, and ${ }^{3}$ Department of Pain Medicine, the Affiliated Hospital of Xuzhou Medical University, Xuzhou, Jiangsu \\ 221002, China
}

Soluble amyloid- $\beta(\mathrm{A} \beta)$ oligomers, also known as $\mathrm{A} \beta$-derived diffusible ligands (ADDLs), are thought to be the key pathogenic factor in Alzheimer's disease $(\mathrm{AD})$, but there is still no effective treatment for preventing or reversing the progression of the disease. Targeting NMDA receptor trafficking and regulation is a new strategy for early treatment of $A D$. $A \beta$ oligomers have been found to bind to the fibronectin (FN) type III repeat domain of EphB2 to trigger EphB2 degradation, thereby impairing the normal functioning of NMDA receptors and resulting in cognitive deficits. Here, we identified for the first time the interaction sites of the EphB2 FN domain with ADDLs by applying the peptide array method to design and synthesize four candidate peptides (Pep21, Pep25, Pep32, and Pep63) that might be able to block the EphB2-ADDL interaction. Among them, Pep63 was found to be the most effective at inhibiting the binding between EphB2 and ADDLs. We found that Pep63 not only rescued the ADDL-induced depletion of EphB2- and GluN2B-containing NMDA receptors from the neuronal surface in cultured hippocampal neurons, but also improved impaired memory deficits in APPswe/PS1dE9 (APP/PS1) transgenic mice and the phosphorylation and surface expression of GluN2B-containing NMDA receptors in cultures. Together, these results suggest that blocking the EphB2-ADDL interaction by small interfering peptides may be a promising strategy for AD treatment.

Key words: Alzheimer's disease; EphB2; interfering peptides; memory deficits; NMDA receptor trafficking; synaptic plasticity

\section{Significance Statement}

Alzheimer's disease $(\mathrm{AD})$ is an age-dependent neurodegenerative disorder and amyloid $\beta$-derived diffusible ligands (ADDLs) play a key role in triggering the early cognitive deficits that constitute AD. ADDLs may bind EphB2 and alter NMDA receptor trafficking and synaptic plasticity. Here, we identified the interaction sites of the EphB2 FN domain with ADDLs for the first time to develop a small (10 aa) peptide (Pep63) capable of blocking the EphB2-ADDL interaction. We found that Pep63 not only rescued the ADDL-induced depletion of EphB2 and GluN2B-containing NMDA receptors from the neuronal surface in cultured hippocampal neurons, but also improved impaired memory deficits in APPswe/PS1dE9 (APP/PS1) transgenic mice. Our results suggest that blocking the EphB2-ADDL interaction with Pep63 may be a promising strategy for AD treatment.

\section{Introduction}

Alzheimer's disease (AD), a progressive and age-related neurodegenerative disorder, is defined in terms of senile plaques and

Received April 22, 2016; revised 0ct. 1, 2016; accepted 0ct. 3, 2016.

Author contributions: X.-D.S. and C.G. designed research; X.-D.S., K.S., R.H., X.-Y.L., Q.-M.H., X.-Y.S., B.Y., and P.W. performed research; X.-D.S., K.S., R.H., N.S., J.-R.H., and Y.H. analyzed data; X.-D.S. and C.G. wrote the paper.

This work was supported by the National Natural Science Foundation of China (Grants 81273489 and 81471101 to C.G. and Grant 81300930 to X.D.S.), the Natural Science Foundation of Jiangsu Province (Grant BK2012582 to C.G. and Grant BK20130232 to X.D.S.), the Education Department of Jiangsu Province (Grant 12KJA180008 to C.G. Grant 14KJB320025 to N.S. and Grant KLYX14-1456 to B.Y.), the Scientific Research Foundation for the Talents by Xuzhou Medical University (Grant D2012005 to X.D.S.), and the Qing Lan Project of Jiangsu Province to C.G. and X.D.S. We thank Prof. Jian-Hong Luo (Zhejiang University) for giving us the anti-GluN2B antibody. neurofibrillary tangles in the brain (Cavallucci et al., 2012). As the major component of senile plaques, amyloid- $\beta(\mathrm{A} \beta)$ is thought to contribute to $\mathrm{AD}$ onset and progression, although the mechanisms are still largely unknown (Cissé and Checler, 2015). Oligomeric $\mathrm{A} \beta \mathrm{s}$, especially soluble $\mathrm{A} \beta$-derived diffusible ligands

The authors declare no competing financial interests.

*X.D.S., K.S., and R.H. contributed equally to this work.

Correspondence should be addressed to Dr. Can Gao, Jiangsu Province Key Laboratory of Anesthesiology, Jiangsu Province Key Laboratory of Anesthesia and Analgesia Application, Xuzhou Medical University, 209 Tongshan Road, Xuzhou, Jiangsu 221004, China. E-mail: gaocan@xzhmu.edu.cn.

DOI:10.1523/JNEUROSCI.1327-16.2016

Copyright $\odot 2016$ the authors $\quad 0270-6474 / 16 / 3611959-15 \$ 15.00 / 0$ 
(ADDLs), seem to be the most neurotoxic species in $\mathrm{AD}$ and are more correlated with cellular and cognitive dysfunction than fibrils (Lambert et al., 1998; Glabe, 2006; Lesné et al., 2006; Ferreira and Klein, 2011).

$\mathrm{A} \beta$ oligomers may contribute to $\mathrm{AD}$ by impairing the normal functioning of NMDA receptors, resulting in the inhibition of NMDA-receptor-dependent long-term potentiation (LTP) (Walsh et al., 2002; Lesné et al., 2006; Shankar et al., 2008; Cissé et al., 2011a). NMDA receptors, which are well known to play an important role in synaptic development and plasticity, are mostly heteromultimers composed of GluN1 and GluN2 subunits (Shankar et al., 2007; Shankar et al., 2008). The function of NMDA receptors is directly dependent on their location and the composition of subunits at synaptic sites (Rao and Finkbeiner, 2007). The protein levels and the phosphorylation status of the NMDA receptor subunits GluN1, GluN2A, and GluN2B are shown to correlate with cognitive performance (Sze et al., 2001). A $\beta$ oligomers can alter the equilibrium and activity of NMDA receptors at synaptic sites, thus triggering a downregulation of NMDA receptor function and associated signaling molecules (Li et al., 2011; Rönicke et al., 2011; Mota et al., 2012). Surface expression of GluN2B-containing NMDA receptors in cortical neurons is found to be reduced by A $\beta 1-42$ (Snyder et al., 2005). Accordingly, the levels of GluN1 and GluN2B subunits are reduced in the hippocampus in $\mathrm{AD}$ (Ikonomovic et al., 1999; Sze et al., 2001). In addition, human amyloid precursor protein (hAPP) transgenic mice carrying high brain levels of $\mathrm{A} \beta$ oligomers have decreased phosphorylation levels of GluN2B in the hippocampus (Palop et al., 2005). The tyrosine 1472 site (Y1472) was found to be the main phosphorylation site of GluN2B.

Several studies have shown that $\mathrm{A} \beta$ oligomers are colocalized with NMDA receptors at synapses (Lacor et al., 2007; Dewachter et al., 2009), but it remains unclear whether there is a direct interaction between them. In recent years, several other proteins at the neuronal surface have been proposed as potential $\mathrm{A} \beta$ oligomer receptors, including cellular prion protein (Laurén et al., 2009), EphB2 (Cissé et al., 2011a), and receptor for advanced glycation end products (RAGE) (Sturchler et al., 2008; Srikanth et al., 2011). Among them, EphB2, which is colocalized with NMDA receptors both in vitro and in vivo (Calò et al., 2006), is a key regulator of synaptic localization of NMDA receptors (Nolt et al., 2011; Sheffler-Collins and Dalva, 2012) and is found to interact with $\mathrm{A} \beta$ oligomers directly (Cissé et al., 2011a). Activation of EphB receptors by ephrinB2 increased NMDA-receptordependent $\mathrm{Ca}^{2+}$ responses and the tyrosine phosphorylation of GluN2B (Takasu et al., 2002). A $\beta$ oligomers bound to the fibronectin (FN) type III repeat domain of EphB2 triggers EphB2 degradation in the proteasome, thereby impairing the normal functioning of NMDA receptors and resulting in cognitive deficits (Cissé et al., 2011a).

Therefore, a potential therapy targeting the interaction between $\mathrm{A} \beta$ oligomers and EphB2 and the subsequent biological cascades could be done by blocking the interaction. In the present study, we identified the interacting sites of the EphB2 FN domain on ADDLs to develop a small interfering peptide Pep63 capable of blocking the EphB2-ADDL interaction effectively. We found that Pep63 not only rescued the impaired synaptic plasticity induced by ADDLs in cultured hippocampal neurons, but also improved memory deficits in APP/PS1 transgenic mice and NMDA receptor trafficking. Our data reveal that blocking the interaction between EphB2 and ADDLs by using small interfering peptides may be a promising strategy for $\mathrm{AD}$ treatment.

\section{Materials and Methods}

Animals. Male mice of 2 different genotypes at the age of 6 months were used. APP/PS1 transgenic mice, which express both a chimeric mouse/ human amyloid precursor protein (Mo/Hu APP 695swe) and a mutant human presenilin 1 (PS1-dE9), and WT mice (nontransgenic littermates of APP/PS1 transgenic mice) were obtained from the Model Animal Research Center of Nanjing University. All mice were housed under standard conditions with 2-4 animals per cage and were kept in a room $\left(22 \pm 2^{\circ} \mathrm{C}\right)$ maintained on a dark/light cycle of $12 \mathrm{~h}$ (8:00 A.M. $-8: 00$ P.M.) with ad libitum access to food and water. All studies were approved by the Animal Care and Use Committee of Xuzhou Medical College in compliance with National Institutes of Health standards.

Drugs. Synthetic A $\beta 1-42$ peptides (Sangon) were lyophilized in 1,1,1,3,3,3-hexafluoro-2-propanol (Sigma-Aldrich) and prepared for ADDLs as described previously (Rönicke et al., 2011). Peptides Pep21, Pep25, Pep32, and Pep63 were synthesized by Pepnoch Biotech. These four peptides were first dissolved in dimethyl sulfoxide (DMSO) and further diluted in Neurobasal medium (Invitrogen) for cultures or artificial CSF (ACSF) containing the following (in mM): $126 \mathrm{NaCl}, 2.5 \mathrm{KCl}, 1$ $\mathrm{MgCl}_{2}, 1 \mathrm{CaCl}_{2}, 1.25 \mathrm{KH}_{2} \mathrm{PO}_{4}, 26 \mathrm{NaHCO}_{3}$, and 20 glucose, $\mathrm{pH} 7.2,320$ mOsm, equilibrated with $95 \% \mathrm{O}_{2} / 5 \% \mathrm{CO}_{2}$ for mice.

Plasmid construction and protein purification. A plasmid for expressing EphB2 (GV287-EphB2) was constructed by Genechem. The cDNA of the EphB2 FN domain was amplified from the template plasmid GV287EphB2 by PCR and cloned into the pET-28a plasmid at the NcoI and XhoI sites, with a tag of six histidine residues being added at the $\mathrm{N}$ terminus. The resulting recombinant plasmid pET-28a-FN was transformed into BL21 (DE3) cells for protein expression under the induction of $0.1 \mathrm{~mm}$ IPTG overnight at $20^{\circ} \mathrm{C}$. FN was purified by nickel-nitrilotriacetic acid chromatography (GE Healthcare). Protein concentrations were determined using BCA assay (Pierce).

Formaldehyde-mediated in vitro chemical cross-linking. To perform formaldehyde cross-linking, ADDLs $(0.5 \mathrm{mg} / \mathrm{ml})$ and FN $(0.5 \mathrm{mg} / \mathrm{ml})$ were mixed and incubated at room temperature (RT) for $30 \mathrm{~min}$. Formaldehyde ( $1 \%, \mathrm{v} / \mathrm{v})$ was added into the mixture for cross-linking ( $15 \mathrm{~min}$ ) before quenching with Tris- $\mathrm{HCl}$ (at a final concentration of $0.5 \mathrm{M}$ ). The cross-linked samples were subjected to SDS-PAGE and immunoblotting analysis.

Coimmunoprecipitation. For the EphB2-ADDL interaction, the hippocampi from Sprague Dawley rats were lysed in cold homogenization buffer containing the following (in mM): 50 MOPS, 320 sucrose, $100 \mathrm{KCl}$, $0.5 \mathrm{MgCl}_{2}, 0.2 \mathrm{DTT}, 50 \mathrm{NaF}, 20 \mathrm{NaPPi}, 20 \beta$-glycerophosphate, 1 EDTA, 1 EGTA, 1 PNPP-Na, $1 \mathrm{Na}_{3} \mathrm{VO}_{4}$, and $0.5 \mathrm{~mm}$ PMSF, along with the following (in $\mu \mathrm{g} / \mathrm{ml}$ ): 10 leupeptin, 10 aprotin, 10 pepstatin $\mathrm{A}$, and 100 benzamidine, $\mathrm{pH} 7.4$, sonicated, and centrifuged at $15,000 \times g$ for $15 \mathrm{~min}$ at $4^{\circ} \mathrm{C}$. After determination of the protein concentration using the BCA assay (Pierce), $500 \mu \mathrm{g}$ of lysate was incubated with ADDLs $(22.5 \mu \mathrm{g})$ in the presence or absence of interfering peptides $(50 \mu \mathrm{g})$ overnight at $4^{\circ} \mathrm{C}$ with $4 \mu \mathrm{g}$ of anti- $\beta$ amyloid and 1-16 (6E10) monoclonal antibodies (Covance) added. For the EphB2-GluN1 interaction, rat primary neurons cultured for $21 \mathrm{~d}$ were treated with $500 \mathrm{~nm}$ ADDLs in the presence or absence of Pep63 $(2.5 \mu \mathrm{g} / \mathrm{ml})$ for $6 \mathrm{~h}$. Cultures were harvested in cold homogenization buffer, sonicated, and centrifuged at $15,000 \times g$ for 15 $\min$ at $4^{\circ} \mathrm{C}$. Then, $500 \mu \mathrm{g}$ of lysate was incubated with $4 \mu \mathrm{g}$ of anti-EphB2 antibodies (R\&D Systems) overnight at $4^{\circ} \mathrm{C}$. Coimmunoprecipitation was performed according to the Catch and Release kit (Millipore) as described in the user's manual. Samples were subjected to SDS-PAGE followed by immunoblotting analysis.

Peptide array assay. Cellulose-bound overlapping peptides (10-mer peptides with 3 aa shift) derived from the EphB2 FN domain were synthesized by Pepnoch Biotech. After activation, membranes were blocked with $5 \%$ sucrose and $4 \%$ nonfat milk in TBST, then incubated with ADDLs $(9 \mu \mathrm{g} / \mathrm{ml})$ followed by $\beta$ amyloid and 1-16 (6E10) monoclonal antibodies (1:1000; Covance). After washing with TBST, membranes were incubated with horseradish peroxidase-conjugated secondary antibodies (1:3000; Beyotime Institute of Biotechnology) for $2 \mathrm{~h}$ at RT. The protein interaction was visualized with an ECL detection system (Beyotime Institute of Biotechnology). 
Hippocampal cultures and treatments. The hippocampi from 18-20 embryonic Sprague Dawley rats were isolated and dissociated with tryp$\sin$ (Gao et al., 2006). Cells were plated on coverslips coated with polyD-lysine in 24-well culture plates or 6-well culture plates and maintained in NeuroBasal medium with B27 (Invitrogen). Half of the medium was replaced with identical medium every $4 \mathrm{~d}$. Cultures were kept at $37^{\circ} \mathrm{C}$ in a humidified incubator with $5 \% \mathrm{CO}_{2} / 95 \%$ air and used for in vitro experiments after $18-21 \mathrm{~d}$ in culture. After stimulation with $500 \mathrm{~nm}$ ADDLs in the presence or absence of interfering peptides, cultures were harvested at indicated time points in cold homogenization buffer. The samples were stored at $-80^{\circ} \mathrm{C}$ if not used immediately and sonicated for subsequent determination of protein concentration and Western blot analysis. Membrane fractions were prepared with the ProteoExtract kit (Calbiochem) for subcellular proteome extraction according to the manufacturer's instructions. Biotinylated proteins were separated by incubating hippocampal neurons with NeutrAvidin agarose (Thermo Scientific) for $1 \mathrm{~h}$ at RT, washed 4 times with wash buffer (with complete protease inhibitors), and eluted with sample buffer at $95^{\circ} \mathrm{C}$.

For activation of EphB2, EphrinB1-Fc or Fc recombinant proteins (R\&D Systems) were dimerized with anti-human Fc antibody (Jackson ImmunoResearch Laboratories) at a 4:1 ratio in Neurobasal medium at room temperature for $90 \mathrm{~min}$. Dimerized ephrinB1-Fc or Fc wasapplied to cultured neurons at $2 \mu \mathrm{g} / \mathrm{ml}$ and incubated at $37^{\circ} \mathrm{C}$ for $20 \mathrm{~min}$.

Immunocytochemistry and quantitative immunofluorescence. Rat primary neurons were grown on coverslips for 16-18 d. After treatment of $500 \mathrm{~nm}$ ADDLs in the presence or absence of interfering peptides (2.5 $\mu \mathrm{g} / \mathrm{ml}$ ) for $6 \mathrm{~h}$, the neurons were rinsed with warm PBS and fixed with $4 \%$ paraformaldehyde in PBS for 10 min at RT. Coverslips were then incubated in blocking solution (5\% normal donkey serum in PBS) for $1 \mathrm{~h}$ at RT and overnight at $4^{\circ} \mathrm{C}$ with polyclonal antibodies recognizing the extracellular N-terminal domain of EphB2 (1:40; R\&D Systems) or GluN2B (1:200; a gift from Prof. Jian-Hong Luo, Zhejiang University) in blocking solution for $1 \mathrm{~h}$ at RT and secondary antibodies conjugated to Cy3 (1:300, goat anti-rabbit; Jackson Immunoresearch Laboratories) or FITC (1:200, donkey anti-mouse; Jackson Immunoresearch Laboratories), respectively, for $1 \mathrm{~h}$ at RT. After extensive washing in PBS, cells were permeabilized with $0.3 \%$ Triton X-100 in PBS for 15 min, blocked with $5 \%$ horse serum or $5 \%$ goat serum in PBS containing $0.1 \%$ Triton X-100 for $1 \mathrm{~h}$, and incubated with polyclonal antibodies to the synaptic marker synaptophysin (1:500; Millipore) at $4^{\circ} \mathrm{C}$ overnight followed by donkey anti-mouse secondary antibodies conjugated to FITC (1:200) or Cy3 (1:300) for $1 \mathrm{~h}$ at RT. Coverslips were rinsed extensively with PBS and mounted with PVD-DABCO. Images were obtained with a QImaging Rolera XR digital camera on an Olympus X81 microscope or an Olympus FV1000 confocal microscope and analyzed with MetaMorph software as described previously (Gao et al., 2006; Gao and Wolf, 2007).

Immunoblotting. After determination of the protein concentration, protein samples were separated by SDS-PAGE and subsequently transferred to PVDF membranes (Bio-Rad). Membranes were blocked by $5 \%$ nonfat milk in TBST, then incubated at $4^{\circ} \mathrm{C}$ overnight with the following primary antibodies: EphB2 (1:1000; R\&D Systems), GluN1 (1:1000; Invitrogen), GluN2A (1:800; Santa Cruz Biotechnology), GluN2B (1:1000; Santa Cruz Biotechnology), p-GluN2B (Y1472) (1:1000; Millipore), p-EphB2 (Y594) (1:1000; Abcam), $\beta$-actin (1:2000; Santa Cruz Biotechnology), and His-tag (1:1000; Zhongshan Goldenbridge Biotechnology). After rinses with TBST, membranes were incubated with horseradish peroxidase-conjugated secondary antibodies (1:1000; Beyotime Institute of Biotechnology). Protein bands were visualized with an ECL detection system (Beyotime Institute of Biotechnology) and quantified densitometrically with ImageJ software.

Morris water maze. The water maze test took place in a round tank (1.2 $\mathrm{m}$ in diameter) filled with white, opaque water. The day before the task, mice were habituated to the environment. During the training phase, mice were allowed to swim with the platform for $90 \mathrm{~s}$ or until they reached the platform, a process monitored by Anymaze software (Stoeling). Animals that did not reach the platform after $90 \mathrm{~s}$ were gently guided toward it. All animals were allowed to remain on the platform for $30 \mathrm{~s}$. The training phase lasted for $5 \mathrm{~d}$, with 4 trials each day. For testing, the latency period for mice to find the platform was recorded $24 \mathrm{~h}$ after the last training session from a starting position different from the last starting position used during the training phase.

Fear conditioning. Contextual and tone-dependent fear conditioning was performed in an automated system (Med Associates) and consisted of a single exposure to a context $(3 \mathrm{~min})$ followed by a $30 \mathrm{~s}$ tone $(10 \mathrm{kHz}$; $75 \mathrm{~dB}$ SPL) and a foot shock ( $2 \mathrm{~s} ; 0.7 \mathrm{~mA}$; constant current) as described previously (Gao et al., 2011). Context-dependent freezing was measured $24 \mathrm{~h}$ later every $10 \mathrm{~s}$ over $180 \mathrm{~s}$ by two observers unaware of the experimental conditions and expressed as a percentage of the total number of observations. Freezing to the tone was similarly scored every $5 \mathrm{~s}$ in a novel context during a $30 \mathrm{~s}$ exposure.

Cannulation and injections. APP/PS1 transgenic mice and WT mice were implanted bilaterally with cannulae into the dorsal hippocampus. Injections were delivered bilaterally $(0.25 \mu \mathrm{l} / \mathrm{side})$ over a $30 \mathrm{~s}$ period at the indicated doses and times relative to the behavioral task. The cannula position was determined for each mouse by methylene blue injection after the end of experiments and only data obtained from mice with correctly inserted cannulae were analyzed.

Statistical analysis. Water maze data were analyzed by repeatedmeasures ANOVA followed by post hoc Student-Newman-Keuls (SNK) multiple comparisons. Other behavior tests and biochemical data were analyzed with one-way ANOVA followed by the SNK, least-significant difference (LSD, for equal variances), or Dunnett's T3 (for unequal variances) for multiple comparisons. Differences were considered significant when $p<0.05$. Data are shown as the mean values \pm SEM.

\section{Results}

ADDLs reduce total and surface expression of EphB2 and surface expression of GluN2B-containing NMDA receptors in cultured hippocampal neurons

To develop small interfering peptides capable of blocking the interaction between EphB2 and soluble $\mathrm{A} \beta$ oligomers to exert neuroprotective effects on APP/PS1 transgenic mice based on the interaction sites of EphB2 on soluble $\mathrm{A} \beta$ oligomers, we first made synthetic $A \beta 1-42$ peptides into ADDLs. The oligomeric nature of ADDLs had been investigated by Western blot analysis and size exclusion chromatography in our previous work (Hao et al., 2015). Then, the effects of prepared ADDLs in cultured hippocampal neurons were confirmed by detecting the total and surface expression of EphB2 and NMDA receptors. Primary neuronal cultures were treated with freshly prepared ADDLs (500 $\mathrm{nM}$ ) for $0,1,3,6$, and $24 \mathrm{~h}$. Subsequently, total and surface proteins were extracted using the ProteoExtract kit and subjected to immunoblotting analysis. Data displayed in Figure $1 A$ indicated that both the total and the surface expression of EphB2 decreased after $3 \mathrm{~h}$ of treatment, with the protein levels reduced to a minimum at $6 \mathrm{~h}$ (T-EphB2: $n=6$ in each group, $F_{(5,30)}=4.954, p=$ 0.002 ; S-EphB2: $n=5$ in each group, $F_{(5,25)}=15.506, p=0.031$ ) (Fig. 1A). As for NMDA receptors, surface expression of GluN2B and GluN1 showed similar changes as that of EphB2 after the treatment of ADDLs (S-GluN2B: $n=8$ in each group, $F_{(5,42)}=$ 21.041, $p=0$; S-GluN1: $n=4$ in each group, $F_{(5,17)}=26.392, p=$ $0.014)$, but the total amount of GluN2B and GluN1 was not changed (T-GluN2B: $n=8$ in each group, $F_{(5,42)}=0.125, p=1$; T-GluN1: $n=4$ in each group, $F_{(5,17)}=0.019, p=0.996$; Fig. $1 B, C)$. Given that the surface expression of GluN2B-containing NMDA receptors is correlated with their phosphorylated level at Y1472 of GluN2B (Salter and Kalia, 2004), we also measured the phosphorylated (pY1472) level of GluN2B. As expected, the immunoblotting results presented in Figure $1 B$ indicated that ADDLs decreased the pY1472 of GluN2B as well (pY1472: $n=5$ in each group, $F_{(5,24)}=3.197, p=0.002$ ). In contrast, neither the total or the surface expression of GluN2A was affected by ADDLs (T-GluN2A: $n=3$ in each group, $F_{(5,16)}=1.017, p=0.694$; S-GluN2A: $n=4$ in each group, $F_{(5,12)}=0.086, p=0.989$; Fig. 
A
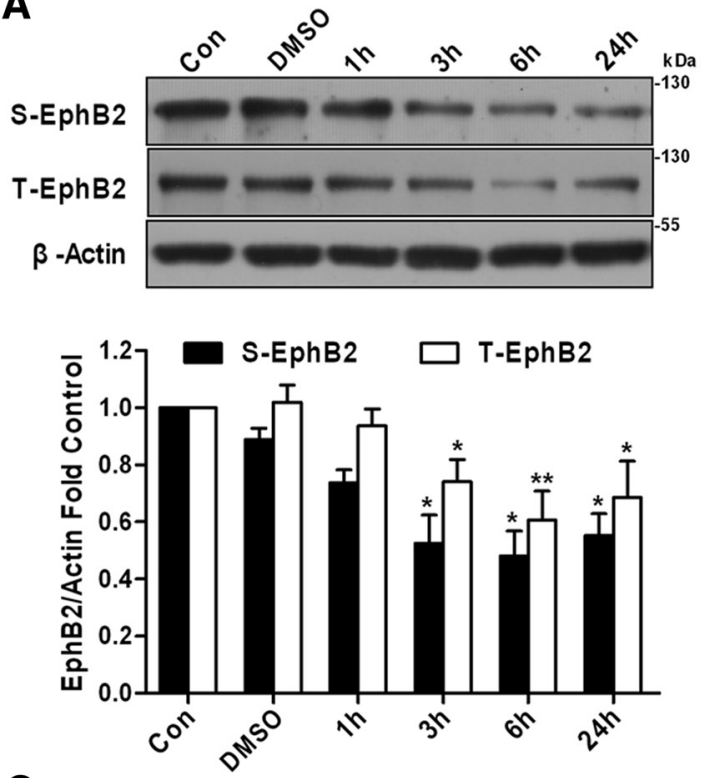

C
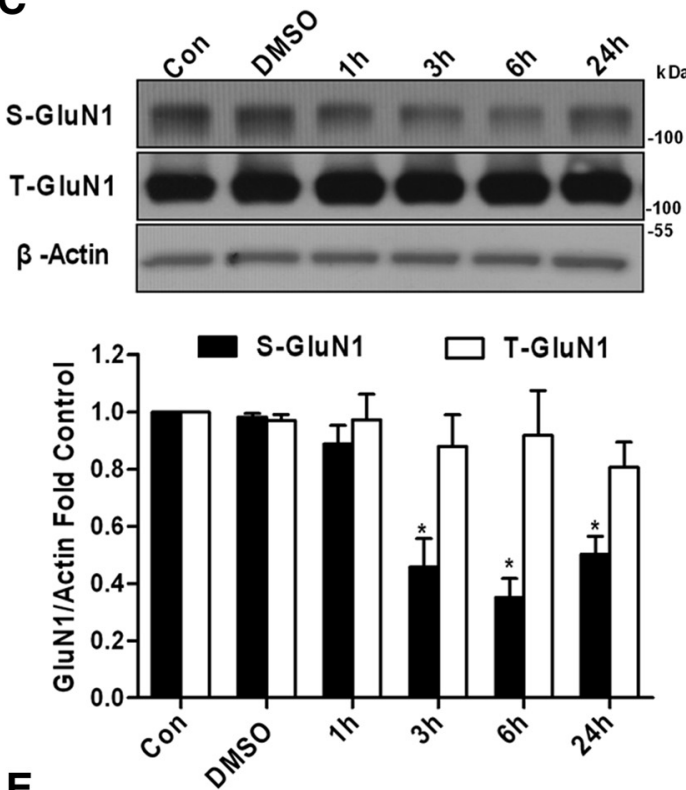

$\mathbf{E}$
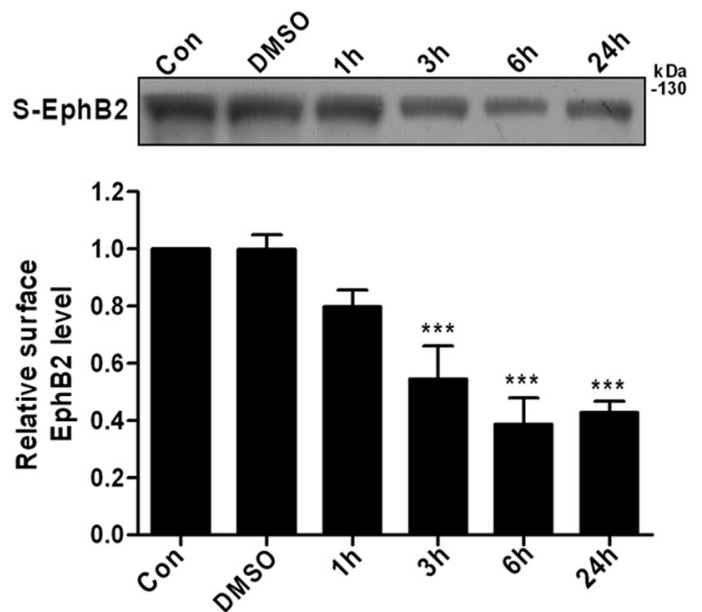

B

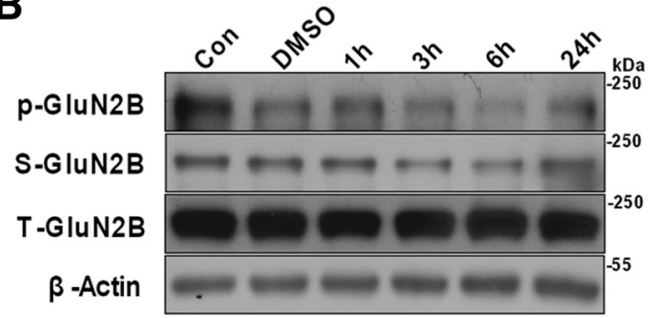

D
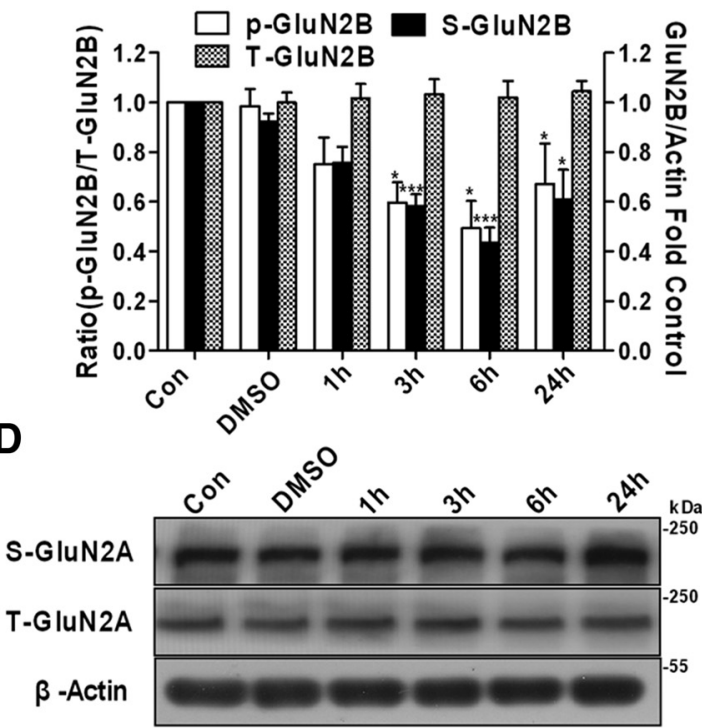

$\mathbf{F}$

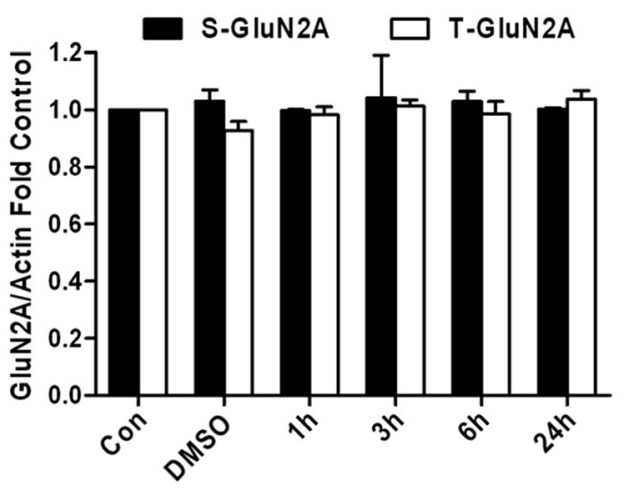

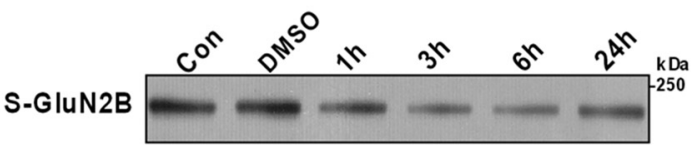

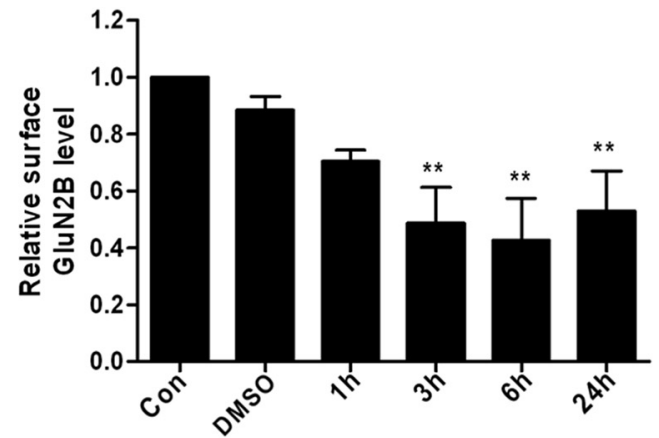

Figure 1. ADDLs reduce total and surface expression of EphB2, as well as surface expression of GluN2B-containing NMDA receptors in cultured hippocampal neurons. $A$, Effect of ADDLs on the expression of EphB2. Both the total and surface expressions of EphB2 were decreased. $\boldsymbol{B}$, Effect of ADDLs on expression of the GluN2B receptor. The surface expression of GluN2B and the phosphorylated level of GluN2B at Y1472 were reduced, whereas the total expression of GluN2B was not changed. C, Effect of ADDLs on expression of (Figure legend continues.) 
$1 D)$. To verify the accuracy of this subcellular extraction method, we further applied a biotinylation assay to detect the effects of ADDLs on the surface expressions of both EphB2 and GluN2B and the results were consistent with those in Figure 1, $A$ and $B$, showing that both the surface expression of these two proteins decreased after $3 \mathrm{~h}$ of ADDL exposure, with the protein levels reduced to a minimum at $6 \mathrm{~h}$ (S-EphB2: $n=4$ in each group, $F_{(5,18)}=15.763, p=0$; S-GluN2B: $n=3$ in each group, $F_{(5,12)}=$ 5.273, $p=0.002$; Fig. $1 E, F)$. Together, these results confirmed that the ADDLs prepared in our laboratory possessed adverse effects in cultured hippocampal neurons by decreasing the total and surface expression of EphB2, as well as the surface expression of GluN2B-containing NMDA receptors.

\section{Determination of the binding sites of the EphB2 FN domain with ADDLs}

We subsequently characterized the interaction between EphB2 and ADDLs. We first performed a coimmunoprecipitation test by applying total hippocampal lysates mixed with ADDLs. As shown in Figure 2A, ADDLs were found to be coimmunoprecipitated with EphB2 from homogenates of the hippocampus, indicating that the ADDLs prepared in our laboratory could interact with EphB2. In addition, we performed coimmunoprecipitation experiment with primary cultures, which was bound with ADDLs followed by a wash, and obtained the same result (data not shown). Given that the FN domain of EphB2 has been shown to be critical for its interaction with $\mathrm{A} \beta$ oligomers (Cissé et al., 2011a), we next determined the interactions between ADDLs and the EphB2 FN domain (FN for short). For this purpose, FN was expressed and purified from Escherichia coli, then subjected to formaldehyde-mediated chemical cross-linking after incubation with ADDLs at RT for $30 \mathrm{~min}$. Formaldehyde cross-linking, which is largely dependent on the number and physical location of lysine residues within the interacting surfaces of proteins, is an effective method to study protein-protein interaction. Here, we applied a short incubation time (15 min) to limit this breadth of cross-linking largely to prevent or avoid significant targetcomplex recovery losses associated with insolubility and precipitation. Data presented in Figure $2 B$ clearly showed that ADDLs cross-linked with FN to form a single band with a molecular weight larger than $25 \mathrm{kDa}$, which reacted with both anti-His tag antibodies and anti- $\beta$ amyloid and $1-16$ (6E10) antibodies, suggesting that ADDLs interacted directly with FN to form complexes. To further determine which residues of the FN domain mediated the binding of ADDLs, ADDLs were incubated with a cellulose membrane containing an array of synthetic 10-mer peptides that were designed to represent the FN domain in an overlapping arrangement (with a 3 aa shift). Dot blotting analysis showed that there were many positive spots, of which four (indicated by arrows in Fig. 2C) were considered potential binding regions because these spots were stained strongly and/or had weak neighboring spots. The peptides represented by these spots were named Pep21, Pep25,

(Figure legend continued.) the GluN1 receptor. The surface expression of GluN1 was reduced, but the total expression of GluN1 was not changed. $\boldsymbol{D}$, Effect of ADDLs on expression of the GluN2A receptor. Neither the total or the surface expression of GluN2A was changed. $E$, ADDLs reduce surface expression of EphB2 with surface biotinylation assay in cultured hippocampal neurons. $F$, ADDLs reduce the surface expression of GluN2B with surface biotinylation assay in cultured hippocampal neurons. ${ }^{*} p<0.05,{ }^{* *} p<0.01,{ }^{* * *} p<0.001$ compared with control (Con). Data are presented as mean \pm SEM.
Pep32, and Pep63. The corresponding peptide sequences are shown in Figure $2 D$.

\section{Pep63 effectively interferes with EphB2-ADDL interaction}

To obtain interfering peptides capable of effectively blocking EphB2-ADDL interaction, four peptide candidates, Pep21, Pep25, Pep32, and Pep63, were synthesized and tested for their ability to inhibit the binding between EphB2 and ADDLs. First, we determined the effect of the presence of these peptides on the coimmunoprecipitation of ADDLs with EphB2 from homogenates of the hippocampus. The results of competitive binding analysis showed that both Pep32 and Pep63 could block the EphB2-ADDL interaction much more effectively than the other synthetic peptides, with the former slightly weaker than the latter (decreased by approximate $60 \%$ and $70 \%$ compared with positive controls, respectively; $n=3$ in each group, $F_{(5,12)}=9.105, p=0.001$ for Pep63 and $p=$ 0.003 for Pep32; Fig. $3 A$ ). We next investigated the protective effects of theses peptides on ADDL-induced dysfunction in cultured hippocampal neurons by detecting the surface expression of EphB2. ADDLs (500 nM) and synthetic peptides $(2.5 \mu \mathrm{g} / \mathrm{ml})$ with approximately the same mass concentration were coincubated in hippocampal neurons for $6 \mathrm{~h}$. Then the surface proteins were extracted and subjected to immunoblotting analysis. Compared with control cells, ADDLs significantly decreased the membrane expression of EphB2. Treatment with Pep32 and Pep63, both of which could effectively block the interaction between EphB2 and ADDLs, led to a remarkable enhancement in the surface expression of EphB2 $\left(n=3\right.$ in each group, $F_{(5,30)}=35.2, p=0$ for Pep32 and $p=$ 0.009 for Pep63; Fig. 3B). In contrast, Pep21 and Pep25, which could not notably inhibit the binding of EphB2 and ADDLs, exhibited a poorly protective effect $(n=3$ in each group, $F_{(5,30)}=35.2, p=0.967$ for Pep2 1 and $p=0.869$ for Pep25). According to the results described above, Pep63 was selected as the interfering peptide to investigate its neuroprotective effects both in vitro and in vivo.

We further attempted to determine the optimal concentration of Pep63 to obtain a neuroprotective effect on cultured hippocampal neurons. Hippocampal neurons were exposed to ADDLs (500 nM) and different concentrations (1.25, 2.5, and 5 $\mu \mathrm{g} / \mathrm{ml}$ ) of Pep63 for $6 \mathrm{~h}$, after which the surface expression of EphB2 was examined. Pep63 significantly rescued the decreased protein levels of EphB2 at all tested concentrations, with the protective effect reaching a maximum at the concentration of 2.5 $\mu \mathrm{g} / \mathrm{ml}\left(n=5\right.$ in each group, $F_{(5,15)}=12.83, p=0$; Fig. $\left.3 C\right)$.

In addition, we investigated the impacts of Pep63 on the activation of EphB2 by detecting the phosphorylated level of EphB2 at pY594 because EphB2 activation can regulate NMDA receptor surface and synaptic localization (Salter and Kalia, 2004). First, we determined whether Pep63 itself could activate EphB2 and results showed that the pY594 of EphB2 did not change upon Pep63 treatment in the cultured hippocampal neurons $\left(n=4\right.$ in each group, $F_{(1,4)}=0.590, p=$ 0.470; Fig. 3D). Second, we investigated whether Pep63 could block the activation of EphB2. We applied ephrinB1 fused with the Fc portion of Ig molecule, which allows ephrinB1 to be dimerized with an anti-Fc antibody to activate EphB2. Cultured hippocampal neurons were treated with dimerized ephrinB1-Fc. As a control, we treated neurons with dimerized Fc alone, which without ephrinB1 attached would not activate EphB2. It was found that the pY594 of EphB2, compared with the control group, increased significantly after treatment 


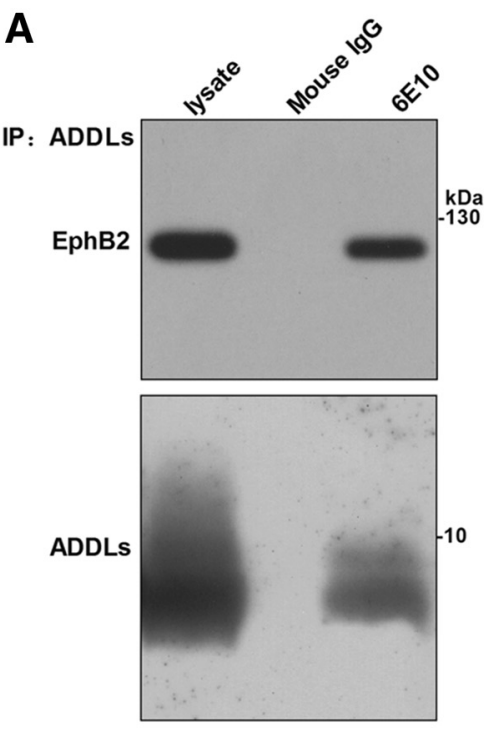

C
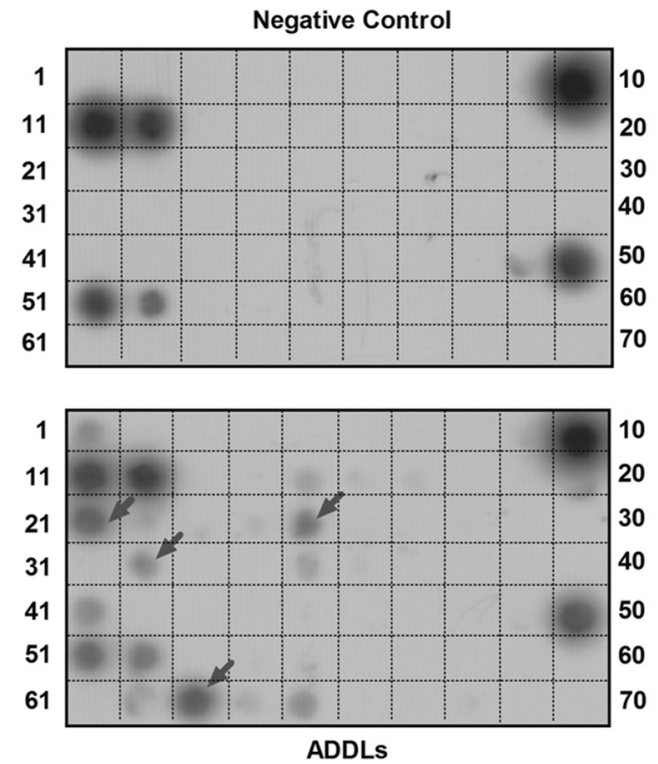

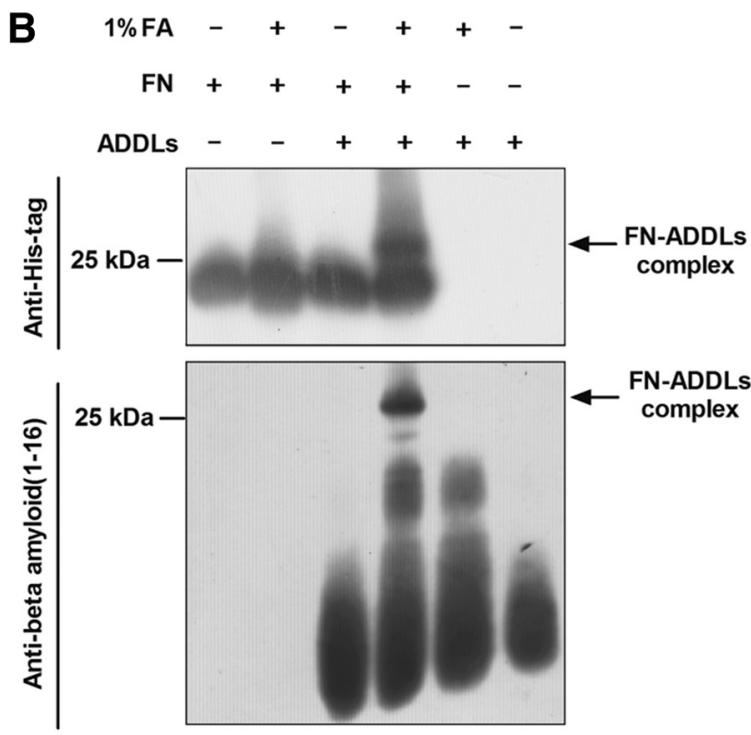

D

\author{
Pep21: V Q Y A PR Q L G L \\ Pep25: PR I Y I S DLLA \\ Pep32: N G V T D Q S P S \\ Pep63: V F Q V RART VA
}

Figure 2. Identification of the binding sites of the EphB2 FN domain on ADDLs. $A$, Prepared ADDLs coimmunoprecipitate with EphB2 from homogenates of the hippocampus. First, $500 \mu$ g of lysate was incubated with ADDLs (22.5 $\mu \mathrm{g}$ ) overnight at $4^{\circ} \mathrm{C}$ with $4 \mu \mathrm{g}$ of anti- $\beta$ amyloid and 1-16 (6E10) monoclonal antibodies (Covance) added. Coimmunoprecipitation was performed according to the Catch and Release kit (Millipore) as described in the user's manual. Samples were subjected to SDS-PAGE followed by immunoblotting analysis using anti-EphB2 antibodies. $\boldsymbol{B}$, Immunoblot results of the formaldehyde-mediated in vitro cross-linked products of ADDLs and FN. ADDLs ( $0.5 \mathrm{mg} / \mathrm{ml})$ and FN (0.5 mg/ml) were mixed and incubated at RT for $0.5 \mathrm{~h}$ before the addition of formaldehyde. After the reaction was quenched by Tris- $\mathrm{HCl}(0.5 \mathrm{M})$, the cross-linked samples were subjected to SDS-PAGE and immunoblotting analysis. $C$, In vitro peptide scan of potential ADDL-interacting sites in the EphB2 FN domain. Overlapping 10-mer peptides with 3 aa shifts derived from the EphB2 FN domain were synthesized on cellulose membranes. Numbers denote the identity of the first and the last peptide of each line of the peptide array. The membrane was incubated with ADDLs and the bound protein was visualized immunologically using the $\beta$ amyloid and 1-16 (6E10) monoclonal antibodies. Dark spots represent the peptides that had bound to ADDLs. Four spots as indicated by arrows were considered as potential binding regions. $\boldsymbol{D}$, Peptide sequences of Pep21, Pep25, Pep32, and Pep63, respectively.

with ephrinB-Fc in the absence of Pep63 $(n=3$ in each group, $\left.F_{(2,6)}=27.872, p=0.002\right)$ and the presence of the Pep63 did not alter the pY594 of EphB2 ( $p=0.093$; Fig. $3 E)$. These results suggest that Pep63 does not affect the activation of EphB2.

It has been demonstrated that EphB2 interacted with the GluN1 subunit of NMDA receptors and this interaction occurred at the cell surface (Dalva et al., 2000). Because Pep63 could rescue the decreased surface expression of EphB2 induced by ADDLs in the cultured hippocampal neurons, we wondered whether the EphB2-
GluN1 interaction would be reduced by ADDLs and if such disruption would be prevented by Pep63. To find out, cultured hippocampal neurons were subjected to ADDLs (500 nM) for $6 \mathrm{~h}$ in the presence or absence of Pep63 $(2.5 \mu \mathrm{g} / \mathrm{ml})$ and then the interaction between EphB2 and GluN1 was determined by coimmunoprecipitation. We found that ADDLs indeed reduced the binding amount of GluN1 with EphB2 $\left(n=3\right.$ in each group, $F_{(3,8)}=12.621, p=$ $0.001)$. Pep63 significantly rescued the decreased GluN1-EphB2 interaction ( $n=3$ in each group, $\left.F_{(3,8)}=20.968, p=0.011\right)$ and Pep63 itself had no effect on the interaction between EphB2 and GluN1 

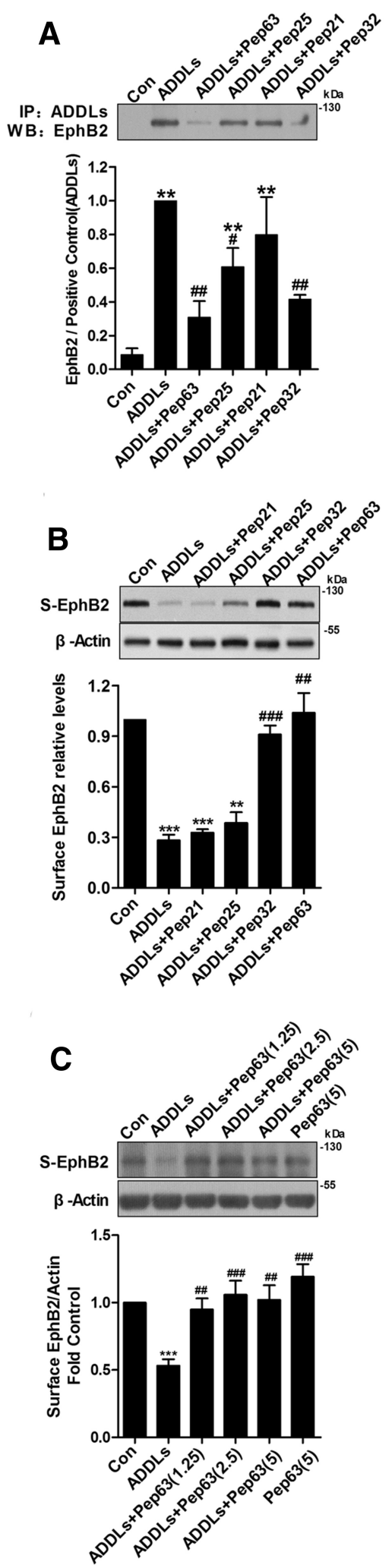

D
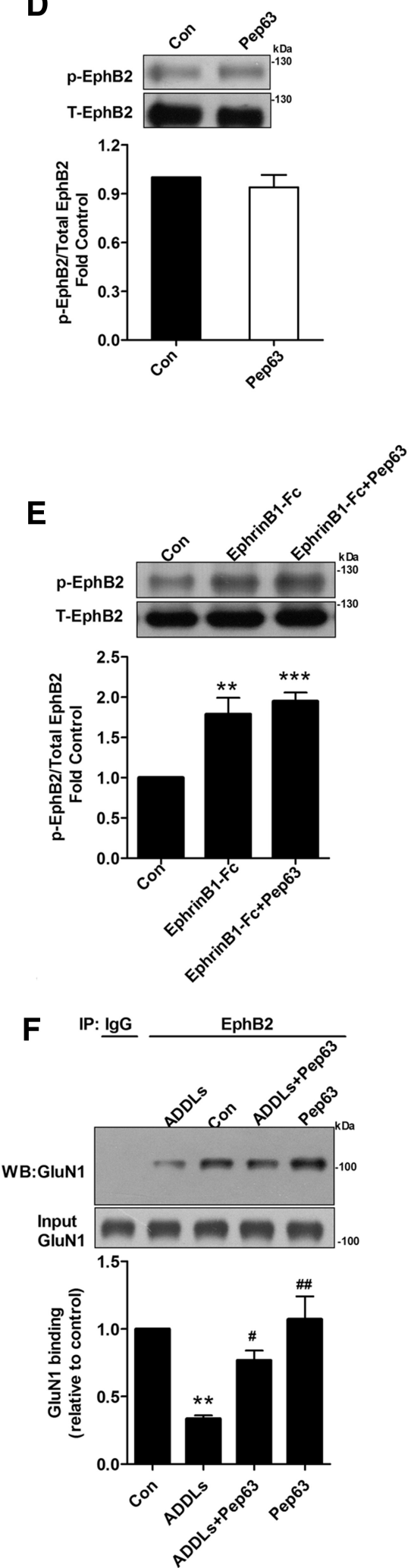

Figure 3. Pep63 effectively interferes with the EphB2-ADDL interaction. $A$, Results of coimmunoprecipitation of ADDLs with EphB2 from hippocampus homogenates in the presence of Pep21, Pep25, Pep32, and Pep63, respectively. Pep32 and Pep63 were found to block the EphB2-ADDL interaction much more effectively than the other synthetic peptides, with the latter being slightly more effective than the former. $\boldsymbol{B}$, Effect of Pep21, Pep25, Pep32, and Pep63 on the decreased surface expression of EphB2 induced by ADDLs in cultured hippocampal neurons. Treatment with Pep32 and Pep63 remarkably rescued the reduced surface expression of EphB2, with Pep63 displaying the best protective effect. C, Identification of the optimal neuroprotective concentration of Pep63 in cultured hippocampal neurons. Pep63 was found to rescue the decreased protein levels of EphB2 induced by ADDLs significantly $(p=0.603$; Fig. $3 F)$. These results demonstrate the specific role of Pep63 in blocking the EphB2-ADDL interaction. The amino acids identical to Pep63 in FN are not involved in the interaction of EphB2 with GluN1.

Pep63 rescues the decreased total and surface expression of EphB2 and the surface expression of GluN2B-

containing NMDA receptors induced by ADDLs in cultured hippocampal neurons

Next, the neuroprotective effect of Pep63 $(2.5 \mu \mathrm{g} / \mathrm{ml})$ against ADDL treatment in cultured hippocampal neurons was investigated. We first studied the protective effect of Pep63 on the total and surface expression of EphB2, both of which were significantly reduced by ADDLs. After treatment with Pep63 for $6 \mathrm{~h}$, the surface expression of EphB2 was rescued by approximately 2 -fold (S-EphB2: $n=5$ in each group, $\left.F_{(3,30)}=22.180, p=0\right)$ and the total amount of EphB2 in the hippocampal neurons was significantly enhanced (T-EphB2: $n=5$ in each group, $F_{(3,20)}=16.684, p=0$; Fig. $\left.4 A\right)$. We subsequently examined the protective effect of Pep63 on the surface expression of the NMDA receptor subunits. The decreased surface expression of both GluN2B and GluN1 induced by ADDLs was remarkably rescued after Pep63 treatment (SGluN2B: $n=6$ in each group, $F_{(3,36)}=$ 33.020, $p=0$; S-GluN1: $n=4$ in each group, $F_{(3,21)}=22.470, p=0.029$; Fig. $4 B)$. The decreased pY1472 of GluN2B was rescued by Pep63 as well (pY1472: $n=5$ in each group, $F_{(3,27)}=21.585, p=$ 0.004; Fig. $4 B$ ).

In addition to immunoblotting analysis, immunofluorescence analysis was applied to confirm the neuroprotective effect of Pep63 on EphB2 and NMDA receptor trafficking. Cultured hippocampal neurons were double stained with $\mathrm{N}$-terminal EphB2

at all concentrations tested; its maximal protective effect was found at a concentration of $2.5 \mu \mathrm{g} / \mathrm{ml}$. D, Detection of the phosphorylated level of EphB2 at pY594 upon Pep63 treatment for $6 \mathrm{~h}$. The pY594 of EphB2 in cells treated with Pep63 was comparable to that of control cells. $E$, Detection of the impacts of Pep63 on the activation of EphB2 by ephrinB1-Fc in cultured hippocampal neurons. $\boldsymbol{F}$, Pep63 prevents the disruption of the EphB2-GluN1 interaction induced by ADDLs. EphB2 immunoprecipitation from cultured hippocampal neurons revealed that the dissociation of EphB2/GluN1 complexes upon ADDLs treatment was restored by exogenous Pep63. ${ }^{* *} p<$ $0.01,{ }^{* * *} p<0.001$ compared with the control group (Con). $\# p<0.05$, \#\#p $<0.01$, \#\#\# < 0.001 compared with the ADDL group. Data are presented as mean \pm SEM. 

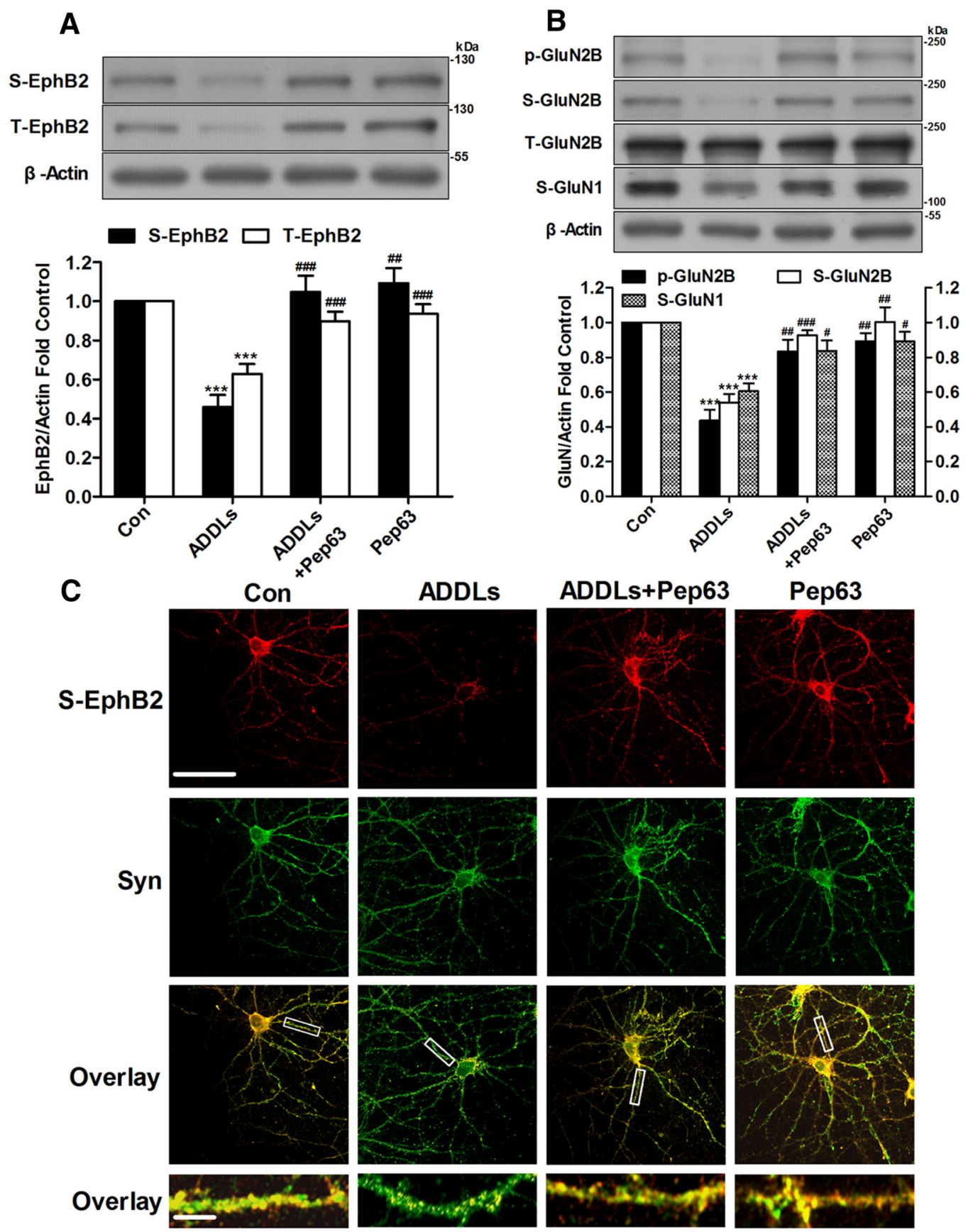

D

E
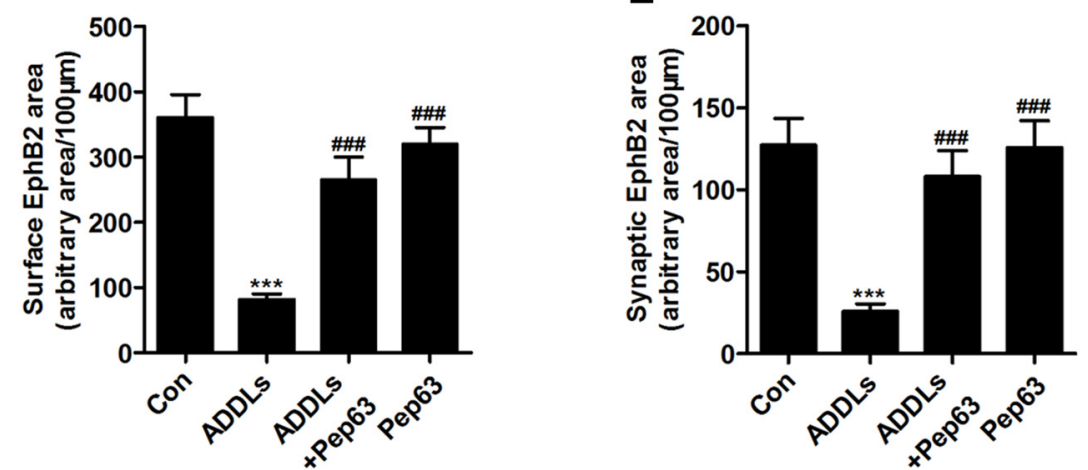

Figure 4. Pep63 rescues the decreased total and surface expression of EphB2 induced by ADDLs in cultured hippocampal neurons. $A$, Pep63 rescues the decreased total and surface expression of EphB2 induced by ADDLs. B, Pep63 rescues the decreased surface expression of GluN2B-containing NMDA receptors induced by ADDLs. The reduced phosphorylated GluN2B at pY1472 was improved as well. C, Double staining against N-terminal surface EphB2 (S-EphB2, red) and synaptophysin (Syn, green) showed that treatment with Pep63 (2.5 $\mu \mathrm{g} / \mathrm{ml})$ (Figure legend continues.) 

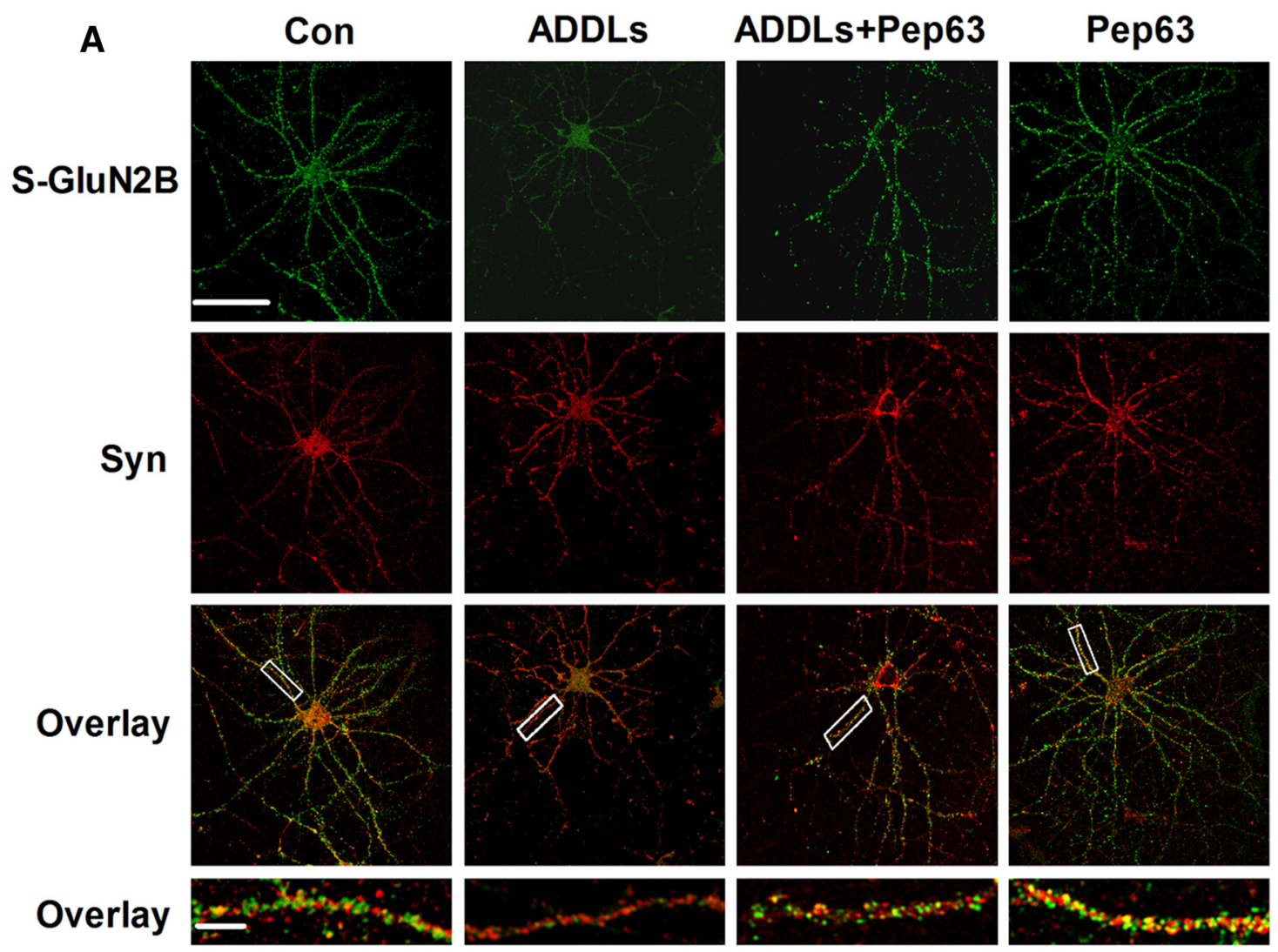

B

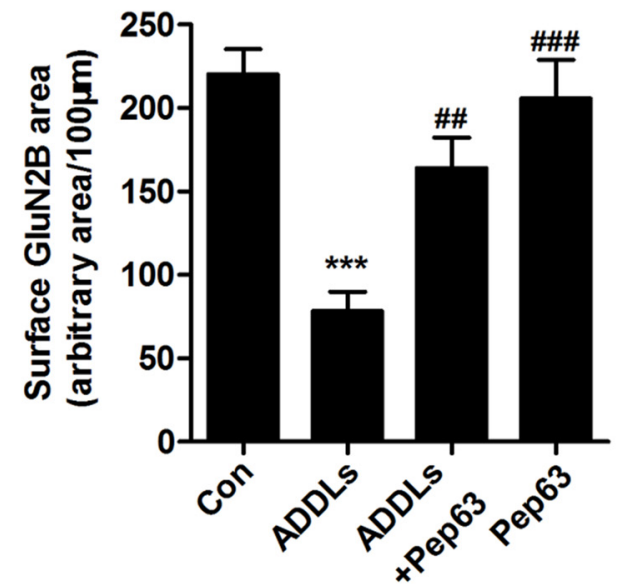

C

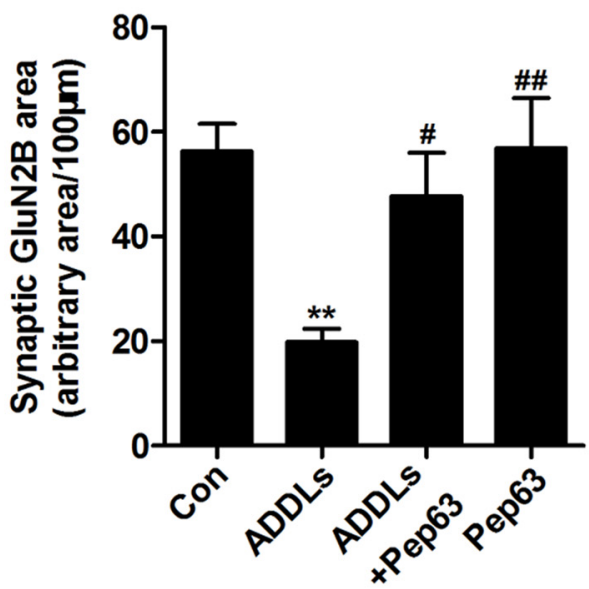

Figure 5. Pep63 rescues the decreased surface and synaptic expression of GluN2B receptor induced by ADDLs in cultured hippocampal neurons. $A$, Double staining against N-terminal surface GluN2B (S-GluN2B, green) and synaptophysin (Syn, red) showed that treatment with Pep63 $(2.5 \mu \mathrm{g} / \mathrm{ml}$ ) rescued both the decreased total surface (green) and synaptic (yellow) expression of GluN2B induced by ADDLs. No change in synaptophysin was observed. Scale bars: top three panels, $70 \mu \mathrm{m}$; bottom panel, $10 \mu \mathrm{m}$. B, Quantitative analysis of the total surface GluN2B area. C, Quantitative analysis of the synaptic GluN2B area. Error bars indicate SEM from at least three independent experiments with 25 cells imaged per experimental condition in each experiment. ${ }^{* *} p<0.01$, ${ }^{* * *} p<$ 0.001 compared with the control group (Con); \#p < 0.05, \#\#p <0.01,\#\#p $<0.001$ compared with the ADDL group. Data are presented as mean \pm SEM.

(Figure legend continued.) rescued both the decreased total surface (red) and synaptic (yellow) expression of EphB2 induced by ADDLs ( $500 \mathrm{~nm}, 6 \mathrm{~h}$ ). No change in synaptophysin was observed. Scale bars, top three panels, $70 \mu \mathrm{m}$; bottom panel, $10 \mu \mathrm{m}$. D, Quantitative analysis of the total surface EphB2 area. $E$, Quantitative analysis of the synaptic EphB2 area. Error bars indicate SEM from at least three independent experiments with 25 cells imaged per experimental condition in each experiment. ${ }^{* * *} p<0.001$ compared with the control group (Con).\#p $<$ $0.05, \# \#>0.01, \# \# p<0.001$ compared with the ADDL group. Data are presented as mean \pm SEM. (surface EphB2, S-EphB2) and synaptophysin (Syn, a presynaptic marker). Our data showed that Pep63 $(2.5 \mu \mathrm{g} / \mathrm{ml}, 6 \mathrm{~h})$ rescued both the decreased surface and synaptic expression of EphB2 induced by ADDLs (500 nM, 6 h; S-EphB2: $F_{(3,58)}=15.126, p=0$; synaptic EphB2: $F_{(3,104)}=12.186, p=0.007$; Fig. $\left.4 C-E\right)$. Similar results were obtained for the surface (S-GluN2B) and synaptic expression of GluN2B (S-GluN2B: $F_{(3,104)}=13.935, p=0.002$; synaptic GluN2B: $F_{(3,104)}=6.185, p=0.018$; Fig. $\left.5 A-C\right)$. These data further demonstrate that Pep63 can improve the decreased surface expression of EphB2 and GluN2B-containing NMDA receptors induced by ADDLs. 
A

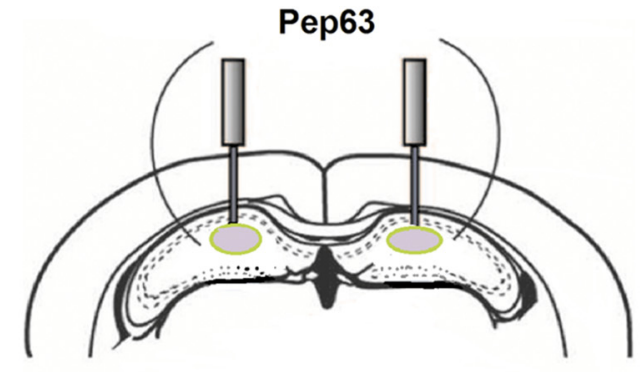

C

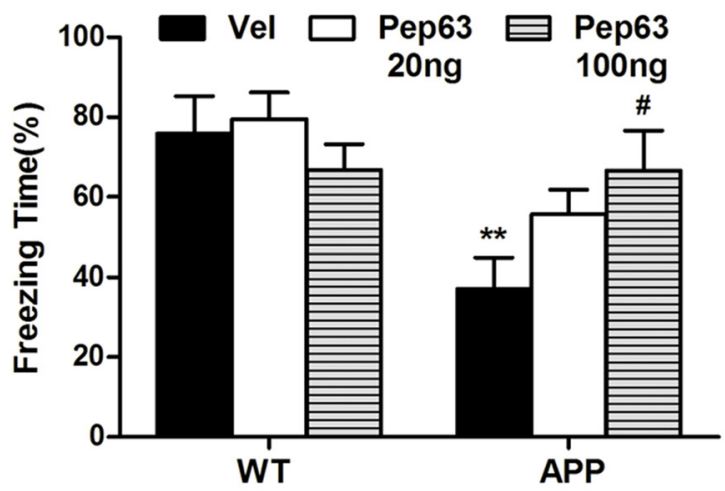

E

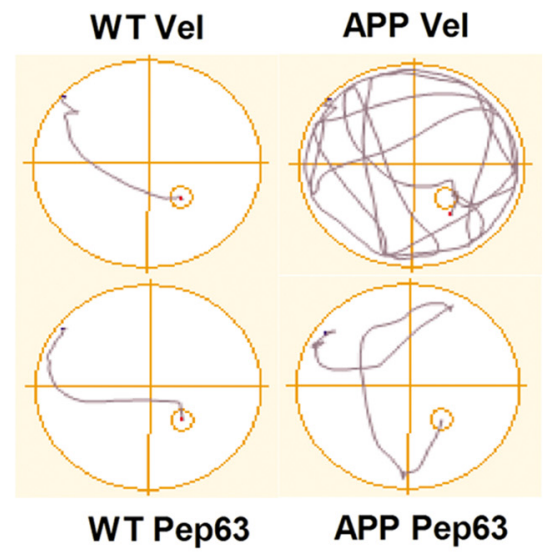

Tone
B

Context

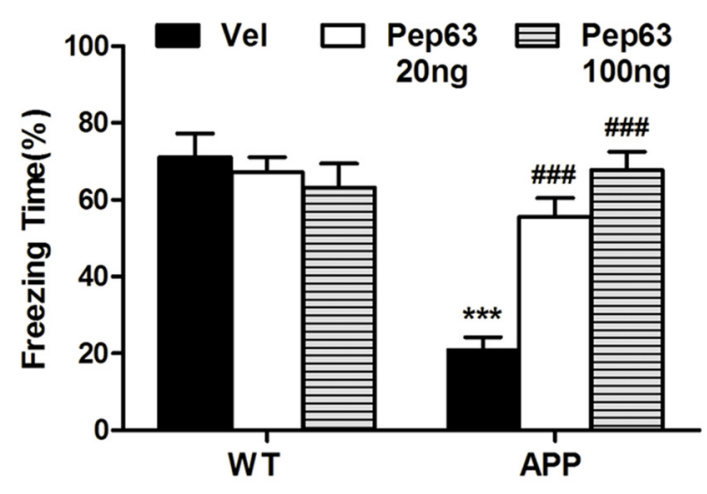

D

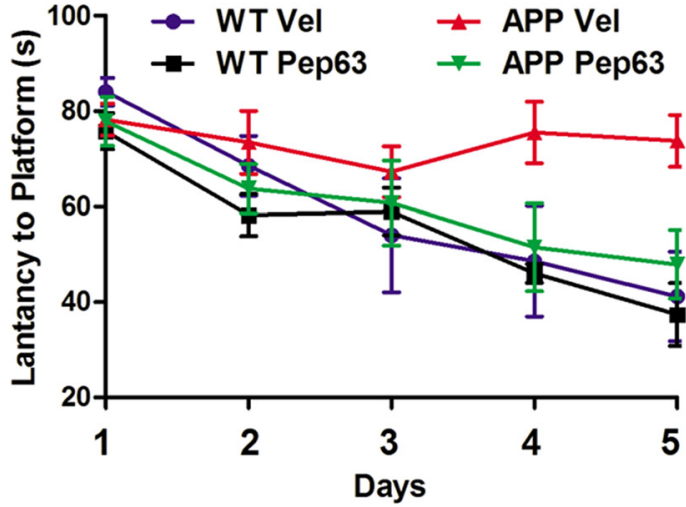

$\mathbf{F}$

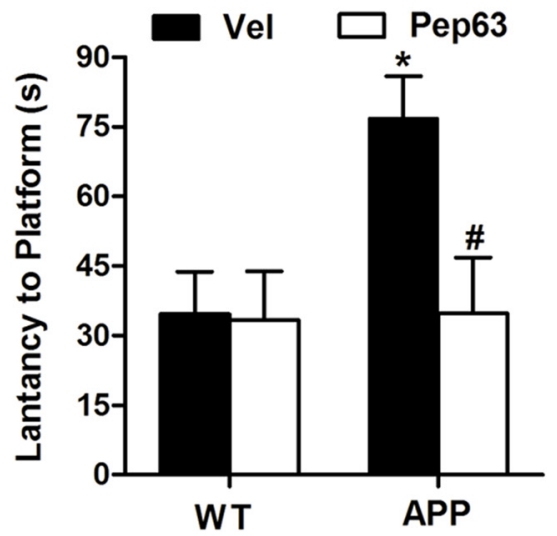

Figure 6. Pep63 improves impaired learning and memory in APP/PS1 transgenic mice. A, APP/PS1 transgenic mice (APP) and WT mice were implanted with double cannulae targeting the dorsal hippocampus and bilaterally injected with Pep63. B, Pep63 (50 and $100 \mathrm{ng}$ ) significantly improved the impaired context-dependent fear memory in APP/PS1 transgenic mice compared with WT mice. C, Pep63 (100 ng) significantly improved the impaired tone-dependent fear memory in APP/PS1 transgenic mice compared with WT mice. D, After training, APP/PS1 transgenic mice injected with Pep63 took less time to reach the platform than that of vehicle mice. $\boldsymbol{E}$, Representative routes to reach the platform. The latency to first reach the platform was recorded $24 \mathrm{~h}$ after the last training session. $F$, APP/PS1 transgenic mice injected with vehicle took longer time to reach the platform compared with WT mice injected with vehicle, while mice injected with Pep63 took less time than those injected with vehicle. ${ }^{*} p<0.05,{ }^{* *} p<0.01,{ }^{* * *} p<0.001$ compared with the WT vehicle group; \#p $<0.05$, \#\#\#p $<$ 0.001 compared with the APP vehicle group. Data are presented as mean \pm SEM. 


\section{Pep63 improves impaired learning and memory in APP/PS1 transgenic mice}

To determine whether blocking the interaction between EphB2 and ADDLs reverses learning and memory deficits in APP/PS1 transgenic mice, Pep63 (20 ng/0.25 $\mu \mathrm{l} / \mathrm{d}$ or $100 \mathrm{ng} / 0.25 \mu \mathrm{l} / \mathrm{d}$ ) or ACSF vehicle was injected bilaterally into the dorsal hippocampus of 6-month-old APP/PS1 transgenic mice and WT mice for $5 \mathrm{~d}$ (Fig. 6A). The fear-conditioning test was applied to detect the protective effect of different concentrations of Pep63. As indicated in the Figure $6, B$ and $C$, both the context- and tonedependent memories were shown to be impaired in 6-month-old APP/PS1 mice. Pep63 of high concentration significantly rescued both the impaired context-dependent fear memory $(n=8$ in each group; $F_{(5,52)}=15.053, p=0$ ) and tone-dependent fear memory $\left(n=8\right.$ in each group; $\left.F_{(5,57)}=2.352, p=0.011\right)$ in APP/PS1 mice. However, Pep63 at a low concentration only significantly improved the impaired context-dependent fear memory $(p=0)$, but failed to display the same protective effect on the tone-dependent fear memory $(p=0.145)$ in APP/PS1 mice. These results demonstrate that Pep63 can improve both the hippocampus-dependent and amygdala-dependent memory loss and the protective effects are concentration dependent. Therefore, a high concentration of Pep63 (100 ng/0.25 $\mu \mathrm{l} / \mathrm{d}$ ) was used in the subsequent tests.

After being injected with Pep63 or ACSF for $5 \mathrm{~d}$, all the animals were trained in the Morris water maze test. After the second trial day, Pep63 had no significant effect on the behavior of the WT mice in the acquisition task (Fig. 6D). In contrast, APP/PS1 transgenic mice injected with vehicle spent much more time in reaching the platform compared with WT mice, whereas APP/ PS1 transgenic mice injected with Pep63 were almost indistinguishable from the WT mice in the acquisition task (Fig. 6D). On the test day, vehicle-injected, but not Pep63-injected, APP/PS1 transgenic mice took longer to reach the original platform location than vehicle-injected WT controls $(n=8$ in each group, $\left.F_{(3,45)}=17.376, p=0.025\right)$, whereas the Pep63-injected WT mice performed similarly to vehicle-injected WT mice $(p=$ 0.968; Fig. 6E,F).

In addition, we examined the protective effect of Pep21, which could not effectively block the interaction between EphB2 and ADDLs, on the impaired learning and memory of APP/PS1 transgenic mice. As expected, unlike Pep63, Pep21 failed to display a protective effect (data not shown).

\section{Pep63 rescues the decreased total and surface expression of EphB2 and the surface expression of GluN2B-containing NMDA receptors in the hippocampus of APP/PS1 transgenic mice}

To further confirm that the protective effect of Pep63 on APP/ PS1 transgenic mice is due to blocking the interaction between EphB2 and ADDLs, we first measured the expression of total and surface EphB2 in the hippocampus of APP/PS1 transgenic mice and WT mice. As indicated in Figure 7, $A$ and $B$, the decreased total and surface expression of EphB2 were significantly rescued by Pep63 in APP/PS1 transgenic mice (T-EphB2: $n=4$ in each group, $F_{(3,16)}=3.347, p=0.047 ; \mathrm{S}-\mathrm{EphB} 2: n=5$ in each group, $\left.F_{(3,15)}=5.319, p=0.006\right)$. We next examined the surface expression of NMDA receptors in the hippocampus. Similarly, Pep63 remarkably rescued the reduced surface expression of GluN2B in $\mathrm{APP} / \mathrm{PS} 1$ transgenic mice $\left(n=5\right.$ in each group, $F_{(3,17)}=4.181$, $p=0.013$; Fig. 7C). Consistently, the decreased pY1472 of GluN2B was obviously rescued as well ( $n=5$ in each group, $F_{(3,15)}=4.01, p=0.013$; Fig. $\left.7 D\right)$. As expected, Pep63 had a similar protective effect on the decreased surface expression of GluN1 ( $n=7$ in each group, $\left.F_{(3,16)}=14.538, p=0.002\right)$, but had no effect on the expression of GluN2A ( $n=7$ in each group, $F_{(3,18)}=0.177, p=0.719$; Fig. $\left.7 F\right)$, supporting our finding that ADDLs did not affect the surface expression of GluN2A in cultured hippocampal neurons (Fig. 1D). These results suggest that the reduced total and surface expression of EphB2 and the surface expression of GluN2B-containing NMDA receptors in the hippocampus, which are relevant to memory loss in APP/PS1 transgenic mice, can be significantly rescued by Pep63.

\section{Discussion}

Overall, we demonstrated that Pep63, a 10-mer peptide that effectively blocked the EphB2-ADDL interaction, represents a novel therapy against $\mathrm{AD}$ via improving impaired memory deficits, as well as the expression of EphB2 and surface GluN2Bcontaining NMDA receptors in the hippocampus of APP/PS1 transgenic mice. We also found that Pep63 prevented ADDLinduced dysfunction of GluN2B-containing NMDA receptor trafficking by improving EphB2 expression and the subsequent effect on GluN2B phosphorylation. Our studies suggest that blocking the EphB2-ADDL interaction with a small peptide could be sufficient to rescue the cognitive dysfunction in $\mathrm{AD}$. This may be a promising strategy for $\mathrm{AD}$ treatment.

\section{Potential therapies targeting the interaction of $\mathrm{A} \boldsymbol{\beta}$ oligomers and $\mathrm{EphB} 2$ in $\mathrm{AD}$}

It is accepted that ADDLs play a prominent role in triggering the early cognitive deficits that constitute AD. Drugs in the former category are designed to inhibit $\beta$ - or $\gamma$-secretase, which releases $\mathrm{A} \beta$ from its precursor (Citron, 2010; De Strooper et al., 2010; Golde et al., 2011). Although Notch-sparing $\gamma$-secretase inhibitors or $\beta$-secretase (BACE1) are still in trials, some clinical trials have been stopped because of side effects that worsen cognitive impairment (Schor, 2011; Huang and Mucke, 2012). Efforts to lower $\mathrm{A} \beta$ levels using an active immunization trial in humans were also stopped due to immunopathological side effects (Gilman et al., 2005; Huang and Mucke, 2012).

Several other experimental strategies have been identified to prevent or reverse hAPP/A $\beta$-dependent neuronal and cognitive impairments in transgenic mice, including reversal of EphB2 expression (Cissé et al., 2011a; Geng et al., 2013). These studies show that $\mathrm{A} \beta$ oligomers bind to the FN repeats domain of EphB2 and trigger EphB2 degradation in the proteasome. Increasing EphB2 expression in the dentate gyrus of hAPP transgenic mice reversed the deficits in NMDA-receptor-dependent memory impairments. Depletion of EphB2 is critical in $\mathrm{A} \beta$-induced neuronal dysfunction. Increasing EphB2 levels or function could be beneficial in $\mathrm{AD}$. Therefore, targeting $\mathrm{A} \beta$ oligomers and the EphB2 interaction and the subsequent biological cascades could be a potential therapy.

Full-length EphB2 contains a ligand-binding domain, a cysteine-rich region, an FN domain, a transmembrane region, a tyrosine kinase domain, a sterile $\alpha$-motif domain, and PSD95, DLG, and ZO1 (PDZ) domains. The FN domain of EphB2, which consists of 203 aa residues, has been demonstrated to be critical for its interaction with $\mathrm{A} \beta$ oligomers (Cissé et al., 2011a). We used a peptide array method to find four 10-mer peptides, Pep21, Pep25, Pep32, and Pep63, that were designed to represent the FN domain and could mediate the binding with ADDLs. Among them, Pep63 effectively interfered with the EphB2-ADDL interaction and affected the levels of EphB2, the phosphorylation of GluN2B, and the surface expression of GluN1/GluN2B. 
A
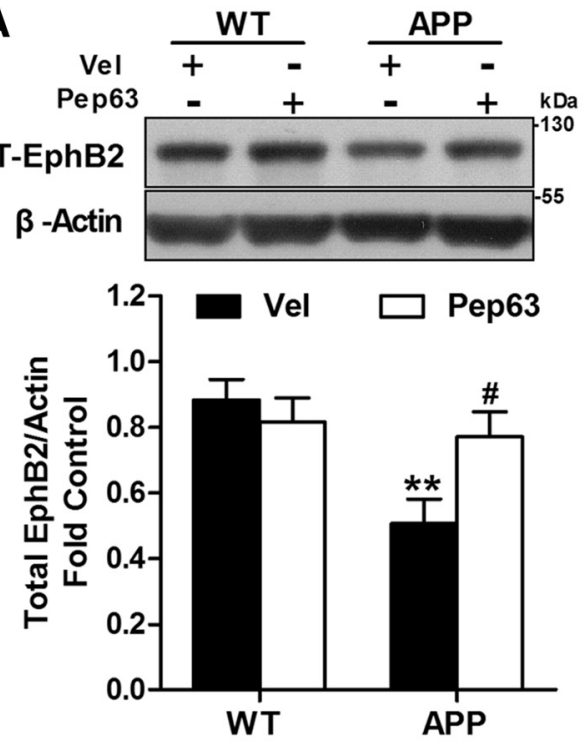

C
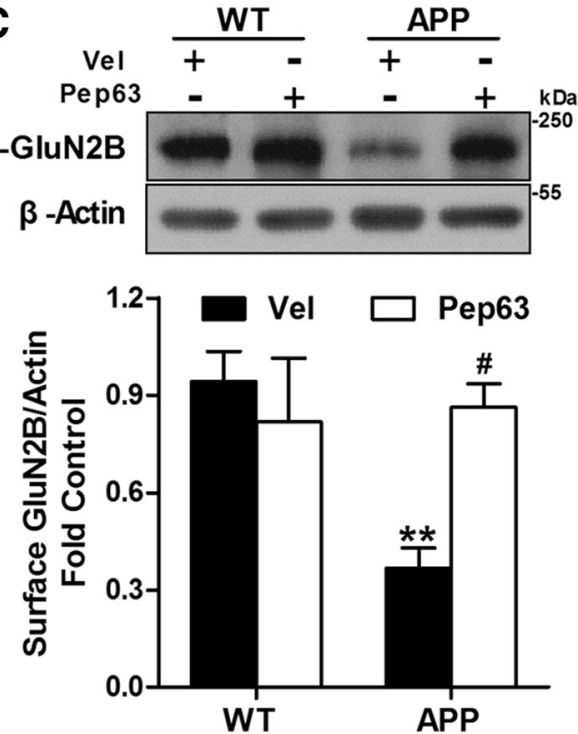

E
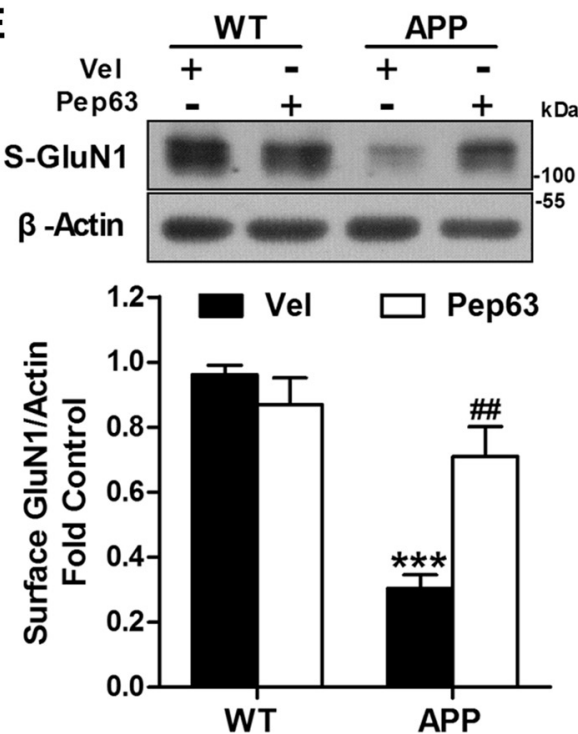
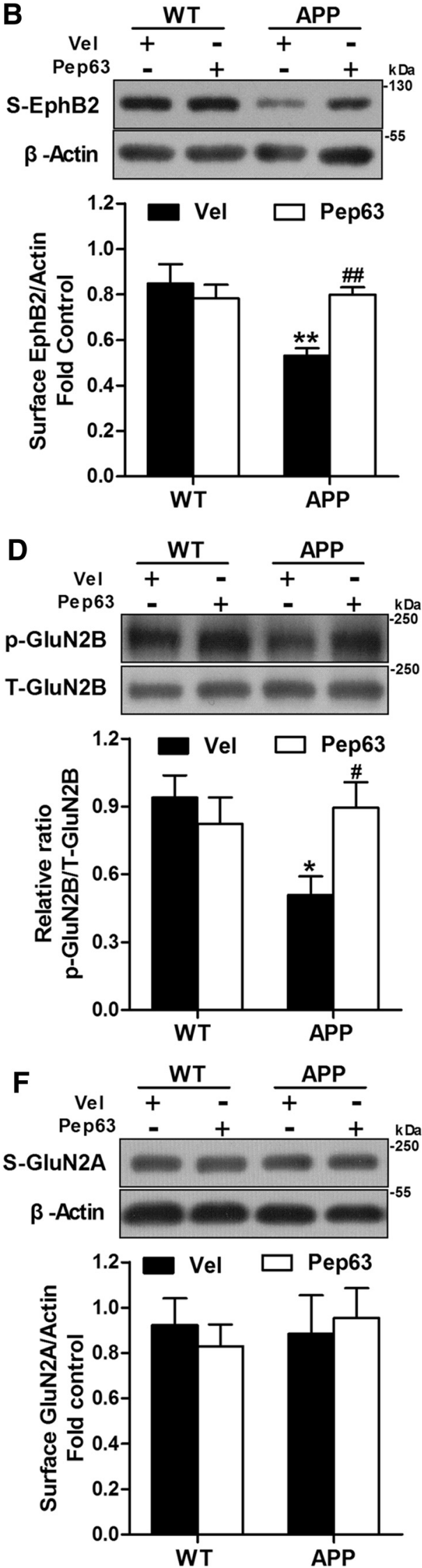

Figure 7. Pep63 rescues the decreased total and surface expression of EphB2 and the surface expression of GluN2B-containing NMDA receptors in the hippocampus of APP/PS1 transgenic mice. $A$, Pep63 significantly rescued the reduced total expression of EphB2 in APP/PS1 transgenic mice (APP). B, Pep63 significantly improved the surface expression of EphB2 in APP/PS1 transgenic mice. C, Pep63 strikingly rescued the reduced surface expression of GluN2B subunits in APP/PS1 transgenic mice. D, Pep63 significantly enhanced the (Figure legend continues.) 


\section{EphB2- and NMDA-receptor-dependent synaptic plasticity dysfunction in $\mathrm{AD}$}

NMDA receptors are important in synaptic plasticity (Collingridge et al., 2004; He et al., 2014). Several studies have demonstrated that $A \beta$ oligomers downregulate the function of NMDA receptors and associated signaling molecules and impair both synaptic plasticity and glutamatergic transmission. Surface expression of GluN1 in cortical neurons is found to be reduced by $\mathrm{A} \beta$ via the activation of the $\alpha-7$ nicotinic receptor and the tyrosine phosphatase STEP (Snyder et al., 2005). Accordingly, the levels of GluN1 and GluN2B subunits are reduced in the hippocampus in AD patients (Ikonomovic et al., 1999; Sze et al., 2001). In addition, hAPP transgenic mice carrying high brain levels of $\mathrm{A} \beta$ oligomers have decreased phosphorylation levels of GluN2B in the hippocampus (Palop et al., 2005). However, little is known about the mechanisms by which $A \beta$ oligomers exert their neurotoxic effects. GluN2B phosphorylation at Y1472 is important for GluN1/GluN2B trafficking to the cell member, which plays an important role in NMDA-receptor-dependent synaptic plasticity. Our results confirmed that ADDLs decreased GluN2B phosphorylation and the surface expression of GluN2Bcontaining NMDA receptors, whereas GluN2A was not affected. Similar results were obtained in APP/PS1 transgenic mice. Pep63 could significantly improve GluN2B phosphorylation and the surface expression of GluN2B-containing NMDA receptors. This indicates that EphB2 is involved in the dysfunction of the trafficking of GluN2B-containing NMDA receptors and synaptic plasticity in AD.

EphB2 expression was also found to be decreased in human AD patients and hAPP transgenic mice (Simón et al., 2009). Upon treatment with $\mathrm{A} \beta$ oligomers, the expression of EphB2 in mature hippocampal neurons was lowered by $60 \%$ (Lacor et al., 2007). EphB2 can regulate the influx of NMDA-receptordependent $\mathrm{Ca}^{2+}$ and the downstream transcription factors involved in LTP formation (Takasu et al., 2002). Mice lacking EphB2 have impaired NMDA-receptor-dependent LTP and memory deficits (Grunwald et al., 2001; Henderson et al., 2001). In mature neurons, EphB2 can enhance the localization of GluN2B-containing NMDA receptors at synapses (Nolt et al., 2011). Furthermore, the gene-targeted depletion of endogenous EphB2 by shRNA reduced the surface levels of the GluN1 subunits of NMDA receptors in primary neurons and impaired the currents of NMDA receptors and LTP in nontransgenic mice (Cissé et al., 2011a). Conversely, peptide EphB2/CTF2 overexpression remarkably increased the surface localization of GluN1 in cell lines and primary neurons (Xu et al., 2009). In addition, increasing EphB2 expression drastically improved the activity of LTP and NMDA receptors in hAPP transgenic mice (Cissé et al., 2011a). In the present study, the EphB2-GluN1 interaction was reduced by ADDLs and such disruption could be prevented by Pep63 via preserving the expression of EphB2. EphB2 may exert its effect via phosphorylation of Y1472 at GluN2B due to its tyrosine kinase activity (Salter and Kalia, 2004). Our results further demonstrated that blocking the interaction between EphB2 and ADDLs by Pep63 (which could preserve the expression of EphB2)

\section{$\leftarrow$}

(Figure legend continued.) phosphorylated levels of GluN2B at pY1472 in APP/PS1 transgenic mice. $\boldsymbol{E}$, Pep63 remarkably rescued the reduced surface expression of GluN1 subunits in APP/PS1 transgenic mice. $\boldsymbol{F}$, Surface expression of GluN2A subunits was not changed and Pep63 had no effect on their surface expression in APP/PS1 transgenic mice. ${ }^{*} p<0.05$, ${ }^{* *} p<0.01,{ }^{* * *} p<$ 0.001 compared with the WT vehicle group; \#p $<0.05$, \#\#p $<0.01$ compared with the APP vehicle group. Data are presented as mean \pm SEM. and the subsequent phosphorylation of GluN2B at Y1472 would improve GluN2B-containing NMDA receptor trafficking. In contrast, a very recent study showed that the protective effect of EphB2 depends on its PDZ-binding motif and association with GluA2, but not on its kinase activity (Miyamoto et al., 2016). The effect of Pep63 on the regulation of AMPA receptors should be studied further.

\section{Role of EphB2 in memory deficits and anxiety in AD}

In the present study, we first found that Pep63, which could block the interaction between EphB2 and ADDLs, improved impaired learning and memory in APP/PS1 mice, including spatial memory (Morris water maze) and associative learning (fear conditioning). The cognitive deficits in the APP/PS1 mouse model, first described by Jankowsky et al. (2001), have been well characterized. Cognitive deficits have been first seen in mice at 3 months of age in the radial arm water maze spatial working memory task and are also reported by 6 months in the Morris water maze test (Cao et al., 2007; Ding et al., 2008), whereas the associative learning described in fear-conditioning tasks start at 6-8 months (Cramer et al., 2012). Both the Morris water maze and fearconditioning results were impaired at 6-7 months in the present study. Interestingly, Pep63 injected into the hippocampus not only rescued impaired context-dependent fear conditioning, which is correlated with both the hippocampus and the amygdala (Maren et al., 2013), but also reversed tone-dependent fear conditioning. The amygdala is believed to be involved in tonedependent fear conditioning (Johansen et al., 2011).

Anxiety disturbances have been reported in some of the $\mathrm{AD}$ mouse models (Lee et al., 2004; Cissé et al., 2011b; Murakami et al., 2011; Filali et al., 2012). Usually, this starts early, at 3-6 months of age, in APP/PS1 models. We also reported that anxiety-like behaviors was found in 9-month-old APP/PS1 mice (Hao et al., 2015). In the present study, we found an anxiety-like behavior in APP/PS1 mice at 6-7 months of age (data not shown). The EphB2-NMDA receptor interaction and downstream signaling in the amygdala are reportedly involved in anxiety (Attwood et al., 2011). It remains to be determined whether the hippocampus-amygdala circuit participates in memory deficits and anxiety behaviors in $\mathrm{AD}$.

In summary, Pep63, which inhibits the binding between EphB2 and ADDLs, rescues impaired synaptic plasticity and memory deficits via improving the total and surface expression of EphB2, as well as the surface expression of GluN2B-containing NMDA receptors in the hippocampus of APP/PS1 transgenic mice. Our studies suggest that blocking the interaction between EphB2 and ADDLs with small peptides could be sufficient to rescue the cognitive dysfunction in $\mathrm{AD}$.

\section{References}

Attwood BK, Bourgognon JM, Patel S, Mucha M, Schiavon E, Skrzypiec AE, Young KW, Shiosaka S, Korostynski M, Piechota M, Przewlocki R, Pawlak R (2011) Neuropsin cleaves EphB2 in the amygdala to control anxiety. Nature 473:372-375. CrossRef Medline

Calò L, Cinque C, Patanè M, Schillaci D, Battaglia G, Melchiorri D, Nicoletti F, Bruno V (2006) Interaction between ephrins/Eph receptors and excitatory amino acid receptors: possible relevance in the regulation of synaptic plasticity and in the pathophysiology of neuronal degeneration. J Neurochem 98:1-10. CrossRef Medline

Cao D, Lu H, Lewis TL, Li L (2007) Intake of sucrose-sweetened water induces insulin resistance and exacerbates memory deficits and amyloidosis in a transgenic mouse model of Alzheimer disease. J Biol Chem 282: 36275-36282. CrossRef Medline

Cavallucci V, D'Amelio M, Cecconi F (2012) Abeta toxicity in Alzheimer's disease. Mol Neurobiol 45:366-378. CrossRef Medline 
Cissé M, Checler F (2015) Eph receptors: new players in Alzheimer's disease pathogenesis. Neurobiol Dis 73:137-149. CrossRef Medline

Cissé M, Halabisky B, Harris J, Devidze N, Dubal DB, Sun B, Orr A, Lotz G, Kim DH, Hamto P, Ho K, Yu GQ, Mucke L (2011a) Reversing EphB2 depletion rescues cognitive functions in Alzheimer model. Nature 469: 47-52. CrossRef Medline

Cissé M, Sanchez PE, Kim DH, Ho K, Yu GQ, Mucke L (2011b) Ablation of cellular prion protein does not ameliorate abnormal neural network activity or cognitive dysfunction in the J20 line of human amyloid precursor protein transgenic mice. J Neurosci 31:10427-10431. CrossRef Medline

Citron M (2010) Alzheimer's disease: strategies for disease modification. Nat Rev Drug Discov 9:387-398. CrossRef Medline

Collingridge GL, Isaac JT, Wang YT (2004) Receptor trafficking and synaptic plasticity. Nat Rev Neurosci 5:952-962. CrossRef Medline

Cramer PE, Cirrito JR, Wesson DW, Lee CY, Karlo JC, Zinn AE, Casali BT, Restivo JL, Goebel WD, James MJ, Brunden KR, Wilson DA, Landreth GE (2012) ApoE-directed therapeutics rapidly clear beta-amyloid and reverse deficits in $\mathrm{AD}$ mouse models. Science 335:1503-1506. CrossRef Medline

Dalva MB, Takasu MA, Lin MZ, Shamah SM, Hu L, Gale NW, Greenberg ME (2000) EphB receptors interact with NMDA receptors and regulate excitatory synapse formation. Cell 103:945-956. CrossRef Medline

De Strooper B, Vassar R, Golde T (2010) The secretases: enzymes with therapeutic potential in Alzheimer disease. Nat Rev Neurol 6:99-107. CrossRef Medline

Dewachter I, Filipkowski RK, Priller C, Ris L, Neyton J, Croes S, Terwel D, Gysemans M, Devijver H, Borghgraef P, Godaux E, Kaczmarek L, Herms J, Van Leuven F (2009) Deregulation of NMDA-receptor function and down-stream signaling in APP[V717I] transgenic mice. Neurobiol Aging 30:241-256. CrossRef Medline

Ding Y, Qiao A, Wang Z, Goodwin JS, Lee ES, Block ML, Allsbrook M, McDonald MP, Fan GH (2008) Retinoic acid attenuates beta-amyloid deposition and rescues memory deficits in an Alzheimer's disease transgenic mouse model. J Neurosci 28:11622-11634. CrossRef Medline

Ferreira ST, Klein WL (2011) The Abeta oligomer hypothesis for synapse failure and memory loss in Alzheimer's disease. Neurobiol Learn Mem 96:529-543. CrossRef Medline

Filali M, Lalonde R, Theriault P, Julien C, Calòn F, Planel E (2012) Cognitive and non-cognitive behaviors in the triple transgenic mouse model of Alzheimer's disease expressing mutated APP, PS1, and Mapt (3xTg-AD). Behav Brain Res 234:334-342. CrossRef Medline

Gao C, Wolf ME (2007) Dopamine alters AMPA receptor synaptic expression and subunit composition in dopamine neurons of the ventral tegmental area cultured with prefrontal cortex neurons. J Neurosci 27: 14275-14285. CrossRef Medline

Gao C, Sun X, Wolf ME (2006) Activation of D1 dopamine receptors increases surface expression of AMPA receptors and facilitates their synaptic incorporation in cultured hippocampal neurons. J Neurochem 98: 1664-1677. CrossRef Medline

Gao C, Frausto SF, Guedea AL, Tronson NC, Jovasevic V, Leaderbrand K, Corcoran KA, Guzmán YF, Swanson GT, Radulovic J (2011) IQGAP1 regulates NR2A signaling, spine density, and cognitive processes. J Neurosci 31:8533-8542. CrossRef Medline

Geng D, Kang L, Su Y, Jia J, Ma J, Li S, Du J, Cui H (2013) Protective effects of EphB2 on Abeta1-42 oligomer-induced neurotoxicity and synaptic NMDA receptor signaling in hippocampal neurons. Neurochem Int 63: 283-290. CrossRef Medline

Gilman S, Koller M, Black RS, Jenkins L, Griffith SG, Fox NC, Eisner L, Kirby L, Rovira MB, Forette F, Orgogozo JM; AN1792(QS-21)-201 Study Team. (2005) Clinical effects of Abeta immunization (AN1792) in patients with $\mathrm{AD}$ in an interrupted trial. Neurology 64:1553-1562. CrossRef Medline

Glabe CG (2006) Common mechanisms of amyloid oligomer pathogenesis in degenerative disease. Neurobiol Aging 27:570-575. CrossRef Medline

Golde TE, Schneider LS, Koo EH (2011) Anti-abeta therapeutics in Alzheimer's disease: the need for a paradigm shift. Neuron 69:203-213. CrossRef Medline

Grunwald IC, Korte M, Wolfer D, Wilkinson GA, Unsicker K, Lipp HP, Bonhoeffer T, Klein R (2001) Kinase-independent requirement of EphB2 receptors in hippocampal synaptic plasticity. Neuron 32:10271040. CrossRef Medline

Hao JR, Sun N, Lei L, Li XY, Yao B, Sun K, Hu R, Zhang X, Shi XD, Gao C (2015) L-Stepholidine rescues memory deficit and synaptic plasticity in models of Alzheimer's disease via activating dopamine D1 receptor/PKA signaling pathway. Cell Death Dis 6:e1965. CrossRef Medline

He Y, Kulasiri D, Samarasinghe S (2014) Systems biology of synaptic plasticity: a review on $\mathrm{N}$-methyl-D-aspartate receptor mediated biochemical pathways and related mathematical models. Biosystems 122:7-18. CrossRef Medline

Henderson JT, Georgiou J, Jia Z, Robertson J, Elowe S, Roder JC, Pawson T (2001) The receptor tyrosine kinase EphB2 regulates NMDA-dependent synaptic function. Neuron 32:1041-1056. CrossRef Medline

Huang Y, Mucke L (2012) Alzheimer mechanisms and therapeutic strategies. Cell 148:1204-1222. CrossRef Medline

Ikonomovic MD, Mizukami K, Warde D, Sheffield R, Hamilton R, Wenthold RJ, Armstrong DM (1999) Distribution of glutamate receptor subunit NMDAR1 in the hippocampus of normal elderly and patients with Alzheimer's disease. Exp Neurol 160:194-204. CrossRef Medline

Jankowsky JL, Slunt HH, Ratovitski T, Jenkins NA, Copeland NG, Borchelt DR (2001) Co-expression of multiple transgenes in mouse CNS: a comparison of strategies. Biomol Eng 17:157-165. CrossRef Medline

Johansen JP, Cain CK, Ostroff LE, LeDoux JE (2011) Molecular mechanisms of fear learning and memory. Cell 147:509-524. CrossRef Medline

Lacor PN, Buniel MC, Furlow PW, Clemente AS, Velasco PT, Wood M, Viola KL, Klein WL (2007) Abeta oligomer-induced aberrations in synapse composition, shape, and density provide a molecular basis for loss of connectivity in Alzheimer's disease. J Neurosci 27:796-807. CrossRef Medline

Lambert MP, Barlow AK, Chromy BA, Edwards C, Freed R, Liosatos M, Morgan TE, Rozovsky I, Trommer B, Viola KL, Wals P, Zhang C, Finch CE, Krafft GA, Klein WL (1998) Diffusible, nonfibrillar ligands derived from Abeta1-42 are potent central nervous system neurotoxins. Proc Natl Acad Sci U S A 95:6448-6453. CrossRef Medline

Laurén J, Gimbel DA, Nygaard HB, Gilbert JW, Strittmatter SM (2009) Cellular prion protein mediates impairment of synaptic plasticity by amyloid-beta oligomers. Nature 457:1128-1132. CrossRef Medline

Lee KW, Lee SH, Kim H, Song JS, Yang SD, Paik SG, Han PL (2004) Progressive cognitive impairment and anxiety induction in the absence of plaque deposition in C57BL/6 inbred mice expressing transgenic amyloid precursor protein. J Neurosci Res 76:572-580. CrossRef Medline

Lesné S, Koh MT, Kotilinek L, Kayed R, Glabe CG, Yang A, Gallagher M, Ashe $\mathrm{KH}$ (2006) A specific amyloid-beta protein assembly in the brain impairs memory. Nature 440:352-357. CrossRef Medline

Li S, Jin M, Koeglsperger T, Shepardson NE, Shankar GM, Selkoe DJ (2011) Soluble Abeta oligomers inhibit long-term potentiation through a mechanism involving excessive activation of extrasynaptic NR2B-containing NMDA receptors. J Neurosci 31:6627-6638. CrossRef Medline

Maren S, Phan KL, Liberzon I (2013) The contextual brain: implications for fear conditioning, extinction and psychopathology. Nat Rev Neurosci 14:417-428. CrossRef Medline

Miyamoto T, Kim D, Knox JA, Johnson E, Mucke L (2016) Increasing the receptor tyrosine kinase EphB2 prevents amyloid-beta-induced depletion of cell surface glutamate receptors by a mechanism that requires the PDZbinding motif of EphB2 and neuronal activity. J Biol Chem 291:17191734. Medline

Mota SI, Ferreira IL, Pereira C, Oliveira CR, Rego AC (2012) Amyloid-beta peptide 1-42 causes microtubule deregulation through N-methyl-Daspartate receptors in mature hippocampal cultures. Curr Alzheimer Res 9:844-856. CrossRef Medline

Murakami K, Yokoyama S, Murata N, Ozawa Y, Irie K, Shirasawa T, Shimizu $T$ (2011) Insulin receptor mutation results in insulin resistance and hyperinsulinemia but does not exacerbate Alzheimer's-like phenotypes in mice. Biochem Biophys Res Commun 409:34-39. CrossRef Medline

Nolt MJ, Lin Y, Hruska M, Murphy J, Sheffler-Colins SI, Kayser MS, Passer J, Bennett MV, Zukin RS, Dalva MB (2011) EphB controls NMDA receptor function and synaptic targeting in a subunit-specific manner. J Neurosci 31:5353-5364. CrossRef Medline

Palop JJ, Chin J, Bien-Ly N, Massaro C, Yeung BZ, Yu GQ, Mucke L (2005) Vulnerability of dentate granule cells to disruption of arc expression in human amyloid precursor protein transgenic mice. J Neurosci 25:96869693. CrossRef Medline

Rao VR, Finkbeiner S (2007) NMDA and AMPA receptors: old channels, new tricks. Trends Neurosci 30:284-291. CrossRef Medline

Rönicke R, Mikhaylova M, Rönicke S, Meinhardt J, Schröder UH, Fändrich, Reiser G, Kreutz MR, Reymann KG (2011) Early neuronal dysfunction 
by amyloid beta oligomers depends on activation of NR2B-containing NMDA receptors. Neurobiol Aging 32:2219-2228. CrossRef Medline

Salter MW, Kalia LV (2004) Src kinases: a hub for NMDA receptor regulation. Nat Rev Neurosci 5:317-328. CrossRef Medline

Schor NF (2011) What the halted phase III gamma-secretase inhibitor trial may (or may not) be telling us. Ann Neurol 69:237-239. CrossRef Medline

Shankar GM, Bloodgood BL, Townsend M, Walsh DM, Selkoe DJ, Sabatini BL (2007) Natural oligomers of the Alzheimer amyloid-beta protein induce reversible synapse loss by modulating an NMDA-type glutamate-receptor-dependent signaling pathway. J Neurosci 27: 2866-2875. CrossRef Medline

Shankar GM, Li S, Mehta TH, Garcia-Munoz A, Shepardson NE, Smith I, Brett FM, Farrell MA, Rowan MJ, Lemere CA, Regan CM, Walsh DM, Sabatini BL, Selkoe DJ (2008) Amyloid-beta protein dimers isolated directly from Alzheimer's brains impair synaptic plasticity and memory. Nat Med 14:837-842. CrossRef Medline

Sheffler-Collins SI, Dalva MB (2012) EphBs: an integral link between synaptic function and synaptopathies. Trends Neurosci 35:293-304. CrossRef Medline

Simón AM, de Maturana RL, Ricobaraza A, Escribano L, Schiapparelli L, Cuadrado-Tejedor M, Pérez-Mediavilla A, Avila J, Del Río J, Frechilla D (2009) Early changes in hippocampal Eph receptors precede the onset of memory decline in mouse models of Alzheimer's disease. J Alzheimers Dis 17:773-786. CrossRef Medline

Snyder EM, Nong Y, Almeida CG, Paul S, Moran T, Choi EY, Nairn AC, Salter
MW, Lombroso PJ, Gouras GK, Greengard P (2005) Regulation of NMDA receptor trafficking by amyloid-beta. Nat Neurosci 8:1051-1058. CrossRef Medline

Srikanth V, Maczurek A, Phan T, Steele M, Westcott B, Juskiw D, Münch G (2011) Advanced glycation endproducts and their receptor RAGE in Alzheimer's disease. Neurobiol Aging 32:763-777. CrossRef Medline

Sturchler E, Galichet A, Weibel M, Leclerc E, Heizmann CW (2008) Sitespecific blockade of RAGE-Vd prevents amyloid-beta oligomer neurotoxicity. J Neurosci 28:5149-5158. CrossRef Medline

Sze C, Bi H, Kleinschmidt-DeMasters BK, Filley CM, Martin LJ (2001) $\mathrm{N}$-methyl-D-aspartate receptor subunit proteins and their phosphorylation status are altered selectively in Alzheimer's disease. J Neurol Sci 182: 151-159. CrossRef Medline

Takasu MA, Dalva MB, Zigmond RE, Greenberg ME (2002) Modulation of NMDA-receptor-dependent calcium influx and gene expression through EphB receptors. Science 295:491-495. CrossRef Medline

Walsh DM, Klyubin I, Fadeeva JV, Cullen WK, Anwyl R, Wolfe MS, Rowan MJ, Selkoe DJ (2002) Naturally secreted oligomers of amyloid beta protein potently inhibit hippocampal long-term potentiation in vivo. Nature 416:535-539. CrossRef Medline

Xu J, Litterst C, Georgakopoulos A, Zaganas I, Robakis NK (2009) Peptide EphB2/CTF2 generated by the gamma-secretase processing of $\mathrm{EphB} 2$ receptor promotes tyrosine phosphorylation and cell surface localization of N-methyl-D-aspartate receptors. J Biol Chem 284: 27220-27228. CrossRef Medline 